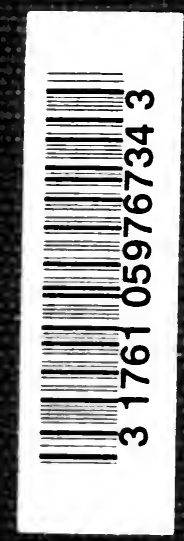

X WORISO COURT

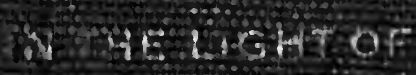

T.WHOSTAES SUPREME COURT

HAOWISS WIILING B.ALCH 


\section{Compliments}

OF THE Author

Phildadelphia 
(.).

$$
\text { - }
$$

$$
\text { • }
$$




\section{Digitized by the Internet Archive in 2007 with funding from Microsoft Corporation}




.


A WORLD COURT

IN THE LIGHT OF

THE UNITED STATES SUPREME COURT 


\section{WORKS BY THE AUTHOR.}

Some facts about Alsace and Lorraine, I895.

The Brooke Family of Whitchurch, Hampshire, England, together with an account of Acting-Governor Robert Brooke of Maryland and Colonel Ninian Beall of Maryland, I899.

The Alabama Arbitration, I900.

Emeric Crucé, rgoo.

The Alasko-Canadian Frontier, I902.

The Alaska Frontier, 1903 .

The English Ancestors of the Shippens and Edward Shippen of Philadelphia, 1904 .

The Swift Family of Philadelphia, 1906.

Balch Genealogica, 1907 .

L'Évolution de l'Arbitrage International, I908.

La Baie d'Hudson, est elle une mer libre ou une mer fermée I9II?

La Baie d'Hudson est une grande mer ouverte, I9r3.

Differends juridiques et politiques dans les rapports des Nations, I9r4.

"Arbitration" as a term of International Law, I9I 5.

The Influence of the United States on the Development of the Law between Nations, I9I 5 .

Legal and Political International Questions and the Recurrence of War, igr6.

The Philadelphia Assemblies, I9r6. 


\title{
A WORLD COURT
}

\author{
IN THE LIGHT OF
}

\section{THE UNITED STATES SUPREME COURT}

\section{THOMAS WILLING BALCH}

L. H. D., Trinity College

Member of the Philadelphia Bar

A Vice-President of the Historical Society of Pennsylvania

Philadelphia

ALLEN, LANE AND SCOTT

1918

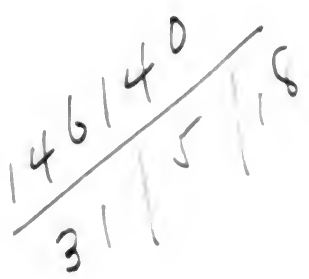


Copyright, rare, by

THOMAS WILLING BALCH

$i$ 
TO

MY MOTHER 


\section{INTRODUCTION.}

U UMANITY has long sought to ward off the 1 ravages and burdens that result from war. The lake dwellers of Switzerland tried to protect themselves against the attack of strangers by building their dwellings above the water on piles far from the shore. The Romans, at the height of their prosperity, built a line of fortifications, Limes Imperii Romani, from the Rhine to the Danube. Those fortifications, inside of which were the medicinal springs of the Taunus region, served against the barbarians of the north as the connecting link between those two rivers that were the northern boulevards on the continent of Europe of the Roman Empire. The Chinese Empire built a long wall extending from the sea inland, for hundreds and hundreds of miles, to keep out the barbarians of the north of Asia. The feudal barons of Europe, as for instance the lords of Coucy-le-Château or Pierrefonds in northern France, built great castles, whose strong walls and high towers afforded them and their retainers and peasants protection against unexpected attack, and also allowed them to levy tribute upon the surrounding lands and any mer- 
chants that ventured within their territory. The burghers of the Middle Ages surrounded their cities with great walls and moats, such as those around the cities of Nürnberg in Germany and Aiguesmortes in southern France, to protect their lives and property against attack and to hold guard upon the surrounding fields from where they drew their food. More recently, Nations have built forts about their frontier towns to check the advance of a hostile army; and in one notable case at least, the northeastern front of France, the whole of one frontier was literally fortified with a chain of forts to aid in repelling invasion. Nations have built great fleets of war vessels. Thus Venice, the United Netherlands, and England have built and maintained great fleets for the double purpose of warding attack from and of safeguarding the commerce of their respective countries, and in the case of Great Britain of assuring in addition the food supply of the Nation. And now the Nations have constructed great fleets of ærial war crafts as an adjunct to their military establishments on land and sea for purposes of attack and defense.

In each of these cases the main object was the same; to afford both a safeguard against attack and invasion of the home, whether that home was a 
small wooden house built above a lake, a strong stone castle, a prosperous city, or the land of a great Nation; and also often at the same time a safe vantage point from which, combined with the requisite mobility, the inhabitants could sally forth to attack strangers to seize upon their wealth.

Within the last half century, however, humanity has turned its attention seriously to developing an additional way of warding off war. Ever since the judicial settlement of the Alabama Claims by the Geneva Tribunal in 1872 , both governments and peoples have sought more and more to perfect the international judicial machinery by which, for the settlement of differences arising between Nations, they would call to their aid jural customs and rules interpreted by International Courts of Justice set up ad hoc. As a result of the call in 1898 of the Emperor Nicholas the Second, for the meeting of the First Hague Peace Conference in 1899, new impetus was given to the efforts to avoid war between the Nations by a resort to legal means. In the first place, provision was made in the legislation enacted by that Conference, in which twentysix of the Nations of the world took part, to facilitate the use of good offices and mediation as means to smooth over the difficulties that arise between 
Nations and which they fail to settle by ordinary diplomatic intercourse. In addition, however, the Conference of 1899 made provisions to facilitate the establishment ad hoc of International Courts of Justice, such as the Geneva Tribunal of I87I-72 that judged the Alabama Claims, and the Paris Tribunal of 1893 that decided the Bering Sea Fur Seal fisheries, to judge causes of difference arising between the Nations instead of allowing the disputing powers gradually to drift, sooner or later, into war.

The Conference of I899 provided for a panel of eminent men, jurists learned in the Law between Nations, from whom two disagreeing Nations could readily constitute an International Tribunal to try the cause of difference between the disputing powers, so soon as the latter had decided to refer their dispute for solution to an International Court of Justice for a judicial decision. ${ }^{1}$ The Second Hague Peace Conference of 1907, at which forty-four of the Nations were represented, perfected the machinery for the calling into being of International Judicial Tribunals, appointed ad hoc, and the American delegation proposed the establishment of a Supreme

${ }^{1}$ A. Pearce Higgins: The Hague Peace Conferences, Cambridge University Press, 1909, page I 26 et seq. 
Court of the World, to be modelled largely upon the Supreme Court of the United States of America.

The Second Hague Conference made improvements in the manner of constituting ad hoc International Tribunals to try cases of discord arising between the Nations. But owing to the refusal of the Powers to agree to the establishment of an International Court composed of a small number of judges, fifteen in number for example, unless each Power was represented upon the Court in the person of a judge, the idea of a Supreme Court of the World sitting in judgment above forty-four Nations, as the Supreme Court of the United States sits upon the forty-eight member States of the North American Union, failed of realization.

Since that time the advocates of the establishment of a Supreme Court of the World have argued that the appointment of judges of The Hague International Courts to try single cases, does not create in the personnel of such temporary and quickly disappearing Tribunals, that esprit de corps and absolutely fearless independence of the pressure of outside public opinion which are so absolutely necessary, except in the case of an exceptional man, in order to obtain judicial judgments based upon the Law instead of political compro- 
mises based upon diplomatic needs and ends. And the advocates of a Supreme Court of the World composed of a small number of jurists appointed for life, maintain that in that way, the existence of the Tribunal, through the life tenure of its members, will be continuous like that of any regularly constituted Municipal Court with life tenure. And that consequently, there will be eliminated from such an International Supreme Court the desire to arrive in formulating its opinion at a compromise which will satisfy both parties, and that decisions will be secured based strictly upon legal rather than upon political or diplomatic grounds.

Happily, to test in a measure through concrete experience what may be expected from a Supreme Court of the World if once set up, we have an analogous example in the Supreme Court of the United States of America. Let us examine in how far that great Court, set up above a number of banded States that had been originally sovereign and that still retain much of their original sovereignty, has succeeded in settling in peace through its decisions the conflicting claims of the various States of the North American Union, at the beginning thirteen, now forty-eight in number. 


\section{PART I.}

When the thirteen colonies revolted in 1775 against the mother country, and then in July, 1776, proclaimed their independence as free, sovereign and independent States, they sought to add, and were successful in their purpose, thirteen members to the family of Nations. Owing to the exigencies of the war, they found it necessary to perfect the loose bond of common opposition to the dictates of Great Britain that united them at first into a more firm alliance, which should preclude the possibilities of their falling out with one another. Accordingly, the Articles of Confederation were drawn up and agreed to by the thirteen States. Before the colonies had broken with the mother land, a fruitful cause of trouble and jealousy between the colonies had been the uncertainty as to the boundaries dividing them. Some of these disputes over the frontier line between two colonies had been settled by some form or other of judicial appeal.

For instance, back in 1650 , the Dutch colony of New Netherland, and the English colonies of New Haven and Connecticut, who for a number 
of years previously did not agree as to the frontier which separated the Dutch and the English possessions in North America, as well as concerning the manner of regulating various matters that had arisen between the settlements of the two nationalities, agreed, largely upon the initiative of Governor Peter Stuyvesant of Amsterdam in New Netherland, ${ }^{2}$ to refer their dispute to a board of adjudication. This board, which consisted of two members appointed by the colony of New Netherland and two named by the colonies of New Haven and Connecticut, met in Connecticut, September 19th, I650. The four members of this board signed a provisional agreement which regulated as fairly as possible for both sides the questions of minor importance, such as that of reciprocity concerning the exchange of prisoners fleeing from justice. In that agreement the Board of Adjudication also agreed upon a provisional frontier line which was to divide the possessions of the Hollanders and the English upon Long Island as well as upon the main land. The colonies of both countries, New Netherland and New Haven and Connecticut, as well

${ }^{2}$ For the correctness of these names, the author is indebted to the learned librarian of the New York Historical Society, Mr. George Kelby. 
as all of their subjects were to recognize that line until the United Netherlands and England in Europe had agreed upon a final and complete settlement of the frontier line. The agreement was in the nature of a modus vivendi merely, since it was to hold good only until it had been ratified, or rejected by the two motherlands. Still it was not only a settlement, so far as the colonies concerned had the power, by means of a quasi-court, but also it was an appeal from the colonies for a final settlement of the questions at issue to the home governments on the other side of the Atlantic. Before the matter could be taken up by the two governments in Europe, however, the United Netherlands and England were again plunged in a European war, one of whose results was the annexation by the English Crown of the colony of New Netherland. Nevertheless, as early as the middle of the seventeenth century, the differences over the boundary between the Dutch colony of New Netherland and the two English colonies of New Haven and Connecticut in North America, were adjusted in a peaceful manner for a period of several years by a mixed commission of representatives of the two contending nationalities. This historic event, of course, was well known to the delegates of New York 
(the successor of New Netherland) and Connecticut in the Constitutional Convention. ${ }^{3}$

The thirteen colonies were practically, owing to the lack of communication through the virgin forest, thirteen distinct settlements or commonwealths, separated from one another by the wilderness, and, through their commerce and their political relations, were in closer touch with the mother country than they were with one another.

In addition, in colonial times, a custom gradually arose among the English speaking North American colonies to refer, sooner or later, their conflicting boundary claims, either to the King in Council or to commissions appointed by the Crown. This manner of carrying the boundary disputes of the colonies to the final judgment of the sovereign aided by his privy council or a commission of his appointment for each case resulted no doubt from the fact that the King in Council was the bond of union not only between England and her colonies but also between each one of the colonies and one and all of the other colonies. In other words, the relations of the colonies to one another and to the

\footnotetext{
${ }^{3}$ Ebenezer Hazard: State Papers, Philadelphia, I 794, Volume II., pages 154-173.-Charles J. Hoadly, Records of the Colony and Plantation of New Haven, 1638-1649, Hartford, 1857, pages 507-536.
} 
motherland through the sovereign and his privy council, caused the colonies to look to the King in Council, as a supreme arbiter or tribunal to decide the boundary disputes between the several colonies.

In Campbell vs. Hall, a case decided in 1774 in the King's Bench, Lord Mansfield said that it was the Law that, a propos of the colonies, the King in Council could not go "contrary to fundamental principles."4

The most important of these boundary cases between the colonies which was settled by an appeal to the English King and his Privy Council, was the disputed frontier between Pennsylvania and Maryland. ${ }^{5}$ In its origin the case went back to the time when Charles the Second made his grant to Penn of territory for a colony in North America. The dispute over the true boundary between the grants to Penn and Baltimore was carried on first by the original disputants and then by their successors. The King in Council was appealed to on more than

'Cowper's Cases in the Court of King's Bench, London, 1800, and edition. Volume I., page 209.

sennsyloania Archives, edited by John B. Linn, and William H. Egle, Second Series, Volume VII., Harrisburg, 1878 ; Ibid, edited by William H. Egle, Second Series, Volume XVI., Harrisbung, $1 \$ 90 .-$ Charles Penrose Keith: Chronicles of Pennsylonio, 1655-17\$\$, Philadelphia, 1917, pages 5-59. 
one occasion. Finally, on May the Ioth, I732, the Lord Baltimore of that day made a formal and written agreement with John, Thomas and Richard Penn providing how the boundary line between the landed possessions of the Baltimores and the Penns should be run. That however did not finally decide the matter, as the two parties still disagreed. There were disorders on the frontiers between the lands possessed by the adherents of the Penns and the Baltimores. A modus vivendi between the respective proprietors was arranged by the Lords for Trade and Plantation, and subsequently on May 25th, I737, the King in Council issued an order for the execution of this temporary settlement without prejudice to either party. As owing to the residence of the Lords Proprietors in England, they were within the jurisdiction of the judicial tribunals of England, the King and his Privy Council agreed meanwhile to a plan whereby the Lord Proprietor of Pennsylvania should bring suit in the Court of Chancery against the Lord Proprietor of Maryland for the specific performance of the agreement of May Ioth, I732, the settlement of their mutual boundary lines, and the confirmation of title to the land. The Penns filed in June, I735, a bill in equity to compel specific performance of the agreement. The decision of 
the Court was to be enforced by an Order in Council. Accordingly, the important case known as Penn vs. Lord Baltimore, was heard and adjudicated in the Court of Chancery by Lord Chancellor Hardwicke.

After careful argument and consideration, the case was decided in favor of the claims of the Penns in behalf of Pennsylvania as against those of the Baltimores for Maryland. To enforce the judgment of the Court of Chancery, an Order in Council in accord with the decision was issued to uphold the legal right of Pennsylvania to exercise her jurisdiction throughout the territory in dispute. This great judicial contest which was submitted through the King in Council to the English Court in Chancery was doubtless well known to the representatives of Pennsylvania, Maryland and Delaware who sat in the Federal Convention, as well as to other members of the body.

There were other cases of conflicting boundaries, arising between the colonies, where an appeal was made to the King in Council. For example, Connecticut in 1754, consulted William Murray, then attorney-general of England, afterwards the celebrated Lord Mansfield, whether an agreement entered into by Connecticut with Massachusetts in 
I 7 I 3 concerning their common boundary line would be set aside by a commission appointed by the Crown. And it was the attorney-general's opinion that after a lapse of more than forty years, the Crown would not help to set aside an agreement in which the two provinces had voluntarily joined defining their mutual frontier.

In I754, two generations and a half after Charles the Second's grant to Penn of Pennsylvania, which grant Penn had reinforced and consummated by actually occupying the province through the establishment of settlements within its bounds, a movement started among the people of the colony of Connecticut to occupy and settle-regardless of the proprietary rights of Penn and his successors under the grant from King Charles the Second-upon some of the lands along the east branch of the Susquehanna River. In I754, the Susquehanna Company, which was composed of Connecticut people, purchased from "the Five Nations of Indians called The Iroquois" for the sum of two thousand pounds of the money current in the colony of New York, lands on the Susquehanna River between the 4Ist and 43rd degrees of north latitude. The grant conveying title from the Iroquois to the Susquehanna Company was signed 
July IIth, I $754{ }^{6}$ The Connecticut colonists based their rights to settle along the Susquehanna, in what became known as the Wyoming Valley, upon the ground that Connecticut stretched westward to the Pacific Ocean, always excepting the territory that belonged to the intervening colonies of New York and New Jersey. It was not, however, until 1763, that people from Connecticut settled in the Wyoming Valley. As might naturally be supposed this appropriation by Connecticut settlers of lands that came within the grant to William Penn, without consulting the proprietors of Pennsylvania, led to a dispute first in words, then in deeds, which ultimately resulted in a state of war on a small scale between the people of Pennsylvania and the Connecticut settlers or intruders as they were called by the Pennsylvanians. In the beginning, the Colony of Connecticut did not countenance the claims of the Susquehanna Company, and did not recognize in any way that the town of Westmoreland in the Wyoming Valley was an integral part of the colony of Connecticut. But owing to the determined opposition of the proprietors of Pennsylvania to the Connecticut settlers, the Assembly

${ }^{6}$ Original manuscript in the collection of the Historical Society of Pennsylvania, Connecticut Claims Papers. 
of Connecticut, after consulting eminent counsel in England, decided on October 2 nd, $1773,{ }^{7}$ to extend its jurisdiction "to those lands contained within the Limits and Bounds of the Charter of this Colony Westward of the Province of New York."

With that object in view, Connecticut sent a committee of three, Colonel Dyer, Dr. Johnson and Jedediah Strong, to Philadelphia to treat with John Penn, the Proprietary Governor of Pennsylvania. ${ }^{8}$ Governor Penn told the gentlemen from Connecticut that there was no need to negotiate as to the boundaries of Pennsylvania and Connecticut. $\mathrm{He}$ maintained that the western bounds of Connecticut had been settled "about two years after the Date of their Charter, under the authority of a Royal Commission, and solemnly assented to, ratified and confirmed by the Governor and Commissioners of their own Colony; that, after this Settlement, the Grant of Pennsylvania was made to William Penn, and that it was not understood at that time by the Crown, nor by the Grantee, William Penn, nor by any other persons since so far as he had heard, that

${ }^{7}$ Pennsylvania Archives, second series, edited by William H. Egle, Harrisburg, I890, Volume XVIII., page I 70.

8 The Public Records of the Colony of Connecticut, edited by Charles J. Hoadly, Hartford, I887, page I6r. 
the said grant any way intrenched upon or approached near, any of the New England grants, till the late claim was set up on the part of Connecticut."9 Governor Penn refused to join in an application to the Crown for the appointment of commissioners as Connecticut wished to review and decide the boundaries between them, "because that would be admitting what he totally denied," to wit, that the territorial claims of Pennsylvania and Connecticut in any way conflicted. Governor Penn maintained "that His Majesty in Council, was the only proper and constitutional Tribunal for a Decision of this kind." As he was anxious to have the difficulty brought before that Court for settlement, if the Colony of Connecticut would not take an appeal of the question to the King and His Privy Council, he would himself invite, Penn said, His Majesty King George to take the matter under consideration.

The more the dispute grew in importance, the more notice it attracted. The Rev. William Smith, Provost of the University of Pennsylvania, ${ }^{10}$ wrote

'Pennsylvania Archives, second series, edited by W. H. Egle, Harrisburg, 1890, Vol. XVIII., page I 71 et seq.

${ }^{10}$ William Smith, D. D.: An Examination of the Connecticul Claim 10 lands in Pennsylvania, 1774; Pennsylvania Archives, second series, edited by W. H. Egle, Harrisburg, 1890 , Volume XVIII., pages $125-214$. 
an essay in support of the rights of Pennsylvania, and Roger Sherman likewise used his pen to maintain the claims of Connecticut. ${ }^{11}$

On the I6th of February, I775, the Proprietors of Pennsylvania, once more as on several occasions in former years, addressed "To the King's most excellent Majesty in Council" a petition in which they examined the question in dispute in detail. ${ }^{12}$ They stated and presented once more much evidence that on previous occasions they had submitted to the King and the Privy Council in support of the grant to Penn and against the Connecticut claims to the Wyoming lands.

Then the petitioners referred to the fact that at the time Charles the Second granted to Penn the charter of Pennsylvania, Connecticut made no objection to the granting of the charter, nor did Connecticut lay claim to lands west of New York and New Jersey until "about the year I755 when it was pretend" $d^{\mathrm{d}}$ " that under the Connecticut charter, the Connecticut people "had a right to skip over

${ }^{11}$ Roger Sherman in John Sanderson's Biography of the signers of the Declaration of Independence, Philadelphia, 1823, Volume III., pages $240-248$.

${ }^{12}$ Manuscript in the collections of the Historical Society of Pennsylvania: Penn MSS., Connecticut Claims. 
New York and New Jersey," and to claim the extent of the latitude of Connecticut westward all the way to the Pacific Ocean or South Sea as it was then called. In that way the Connecticut people would take away one-third of the land that Charles the Second had granted to William Penn. Many other pertinent facts were presented in support of the claims of the Proprietors of Pennsylvania to the Wyoming Valley lands. The petition finished by praying His Majesty the King to declare that Connecticut was bounded on the west by the Province of New York.

Then as the struggle between the thirteen English colonies and their mother country developed, and the possibility of Pennsylvania appealing the Wyoming controversy to the King in Council passed away, Pennsylvania brought that dispute to the notice of the Continental Congress.

On September 3oth, 1775, the Assembly of Pennsylvania discussed "the Intrusion of a Number of People into this Province, under a pretended Claim of the Colony of Connecticut, to the great Annoyance of the good People of this Province," and instructed the Pennsylvania delegates in the Continental Congress, which was sitting in Philadelphia in the Pennsylvania State House, 
to bring the dispute to the attention of the Congress. ${ }^{13}$

Accordingly in the early days of October, 1775, Ross of the Pennsylvania delegation in the Congress, presented to the latter body this resolution of the Pennsylvania Assembly. John Rutledge of South Carolina moved that the papers should be referred to the delegates of the two colonies. Thomas Willing, one of the Pennsylvania delegation and also a Justice of the Supreme Court of that Province, pointed out that the delegates of the two colonies were interested parties to the controversy and said that they would need an umpire to reach a settlement. Roger Sherman, a Connecticut delegate, thought the two delegations might be able to agree on a temporary line. ${ }^{14}$

After the delegations of the two States, to whom Congress had submitted the matter, could not come to an agreement concerning the question, the whole matter was referred to a committee consisting of Rutledge, Chase, Jefferson, Kinsey and

${ }^{13}$ Votes and Proceedings of the House of Representatives of the Province of Pennsylvania, Philadelphia, I776, Volume VI., page 6rg.

${ }^{14}$ John Adams: Works, Boston, r850, Volume II., page 465. 
Hopkins. ${ }^{15}$ As time passed, the people of Pennsylvania and the Connecticut intruders came to blows and blood was shed. On December 2oth, 1775, Congress decided that the contending parties should at once stop all hostilities, "until the dispute can be legally decided." 16 Finally, as the result of the ill feeling engendered, troops had to be sent to the seat of trouble to keep the peace between them. ${ }^{17}$ Owing to the war with Great Britain, however, these troops were soon ordered to join General Washington and the Wyoming colonists found themselves left on the frontier to repulse an attack of the English and the Indians.

When the war for independence started, besides the Pennsylvania-Connecticut controversy there were several other boundary disputes outstanding between several of the newly born Nations, and in the Articles of Confederation special provision

1s Journal of the Continental Congress, 1774-17\$9, edited by Worthington C. Ford, Washington, 1905, Volume III., page 295.-John Sanderson: Biography of the Signers of the Declaration of Independence, Philadelphia, 1823 , page 250.

16 Journal of the Continental Congress, 1774-1789, edited by Worthington C. Ford, Washington, 1905, Volume III., page 439.

17 Journal of the Continental Congress, $1774-1789$, edited by Worthington C. Ford, Washington, 1906, Volume V., pages 698-9. 
was made looking to the peaceful settlement of the disputed frontiers and land grants. Under the Articles of Confederation, the United States had no judicial department. But by the ninth article of that agreement, provision was made for the establishment of a series of Courts of Appeal to try differences between the various colonies, each Court being established ad hoc to hear one particular case.

The Articles of Confederation went into effect in I78I, and the State of Pennsylvania, following her earlier practice in the controversy, when she was a colony, of appealing this case to the King in Council, petitioned Congress on November 3rd, I78I, according to the ninth article, for a hearing to settle the question. ${ }^{18}$ There were many delays. On November I4th, I78I, Congress agreed to appoint June 24th, I782, as the date for Pennsylvania and Connecticut to put in an appearance, "by their lawful agents, at the place in which Congress shall then be sitting," ${ }^{19}$ and the Congress further voted to send a formal notice to the legislative authorities of the

18 Journal of Congress, Philadelphia, I800, Volume VII., page I69.

19 Journal of Congress, containing their proceedings from January I, I781, to November 2, I782, Philadelphia, I800, Volume VII., page 174 . 
State of Connecticut that that Commonwealth, as well as Pennsylvania, must put in an appearance before Congress on June 24th, I782. Accordingly, on the appointed day, Pennsylvania appeared before Congress through her properly accredited counsel, William Bradford, Joseph Reed, James Wilson and Jonathan Dickinson Sergeant, and her solicitor, Henry Osborn. Connecticut had appointed Eliphalet Dyer, William Samuel Johnson and Jesse Root to represent her on that occasion, but only Dyer was present and so the question had to be continued until the next month. ${ }^{20}$

On July I6th, the matter was again taken up. Pennsylvania was represented by Wilson and Sergeant, with Osborn as their solicitor, and Connecticut by Dyer and Root. After some discussion Congress finally resolved;

"That the agents of Pennsylvania and Connecticut be, and they are hereby directed to appoint by joint consent, commissioners or judges to constitute a Court for hearing and determining the matter in question, agreeably to the 9th article of the Confederation." 21

20 Journal of Congress: Philadelphia, 1800 , Volume VII., page 302.

21 Journal of Congress: Philadelphia, 1800, Volume VII., page 315. 
On August 12th, 1782, the agents for the Commonwealth of Pennsylvania and the State of Connecticut reported that, in accordance with the resolution of Congress of July I6th, they had appointed as "commissioners to constitute a court for hearing and determining" the controversy between Pennsylvania and Connecticut, William Whipple of New Hampshire, Nathaniel Green of Rhode Island, David Brearly and William Churchill Houston of New Jersey, Cyrus Griffin and Joseph Jones of Virginia, and John Rutledge of South Carolina. ${ }^{22}$ "Any five or more of whom," the agents went on to say in their report, "we have agreed shall constitute a Court, and have authority to proceed and determine the matter and difference between the said States." However, Nathaniel Green and John Rutledge declined to serve, and Thomas Nelson of Virginia, and Welcome Arnold, of Rhode Island, were named in their stead. ${ }^{23}$ Congress ratified the appointments. $^{24}$

22 Journal of Congress: Philadelphia, r800, Volume VII., page $33 \mathrm{r}$.

${ }^{23}$ Journal of Congress: Philadelphia, I800, Volume VII., page 336.

${ }^{24}$ Journal of Congress: Philadelphia, I800, Volume VII., page 336. "Whereupon, Ordered, That the secretary prepare and report the draught of a commission for the said William Whipple, Welcome Arnold, David Brearly, William Churchill Houston, Cyrus Griffin, 
The Court was commissioned to convene at Trenton, in the State of New Jersey. On November 8 th, I782, a quorum of the members of the Tribunal being in attendance, the Court began to try the case and sat for that purpose until December 3oth. The counsel for Pennsylvania were James Wilson, Joseph Reed, Jonathan D. Sergeant and William Bradford. Connecticut was represented by Eliphalet Dyer, Jesse Root and William S. Johnson. ${ }^{25}$ The arguments of counsel have not come down to us, but the briefs have, and show great learning and much work on the part of the legal representatives of both States in their efforts to win the case for their respective Commonwealths.

Before the members of the Trenton Inter-State Court decided the case, they agreed that the reasons for their conclusions should never be given, and that the decision should go forth to the world as the unanimous opinion of the Court.

The decision of the Court was handed down on

Joseph Jones and Thomas Nelson, or any five or more of them, as commissioners or judges nominated by the States of Pennsylvania and Connecticut, to determine the dispute between the said States agreeable to the gth article of the Confederation."

${ }^{25}$ Pennsylvania Archives, second series, edited by William H. Egle, Harrisburg, 1890, Volume XVIII., page 621. 
December 3oth. It was concise, clear and final. The Court held:

"This Cause has been well argued by the Learned Council on both sides.

"The Court are now to pronounce their Sentence, or Judgment.

"We are unanimously of Opinion that the State of Connecticut has no right to the Lands in controversy.

"We are also unanimously of Opinion that the Jurisdiction and Preemption of all the Territory lying within the Charter boundary of Pennsylvania and now claimed by the State of Connecticut do of Right belong to the State of Pennsylvania.

\section{"WM. WHIPPLE WELCOME ARNOLD DAV'D BREARLY CYRUS GRIFFIN WM. C. HOUSTON}

“Trenton, 3oth Dec'r. I782."

The decision effectually put an end to the dispute of jurisdiction and possession as to whether Pennsylvania or Connecticut was entitled to the lands that both States claimed. As soon as the 
decision was known, President John Dickinson of Pennsylvania issued a proclamation forbidding any violence on the part of individuals to gain possession of disputed land claims. One of the judges of the Court, Griffin, in a letter to President Dickinson said: "this I will undertake to say, that no Court ever met and decided a great question less subject to partiality or corruption, or in which more candor and freedom of debate were exercised * * * I can assure you, sir, that the commissioners were unanimously of opinion that the private right of soil should not be affected by the decision." ${ }^{26}$

The decision shows conclusively that the Trenton Inter-State Tribunal sat as a Court to award justice upon legal grounds, and not as a board of mediation to effect a reconciliation of the conflicting claims upon the basis of a compromise.

Commenting on this case, Judge Henry Wade Rogers has said: "The fact that the defeated sovereignty acquiesced, although Congress had no power given it to enforce judgment, is without much significance. A State as small as Connecticut would not be likely to make war upon a State the size of Penn-

${ }^{20}$ Pennsyloania Archives, second series, Harrisburg, 1890, pages $631-632$. 
sylvania over such a dispute." Besides, Connecticut could not have passed her troops across the territory of New York without encroaching upon the neutrality of the latter commonwealth, and so probably involving New York against Connecticut in the contest. Consequently, Connecticut could only have made war upon Pennsylvania after transporting her troops by sea, and the trip from the Connecticut ports to Philadelphia and the other Pennsylvania towns on the Delaware River was far longer and more difficult in $\mathbf{I 7 8 2}$ than it is to-day. In addition, another compelling reason for the acquiescence of Connecticut in the decision of the Trenton Inter-State Tribunal was the war for independence which was still going on. All of the eleven other States, as well as Pennsylvania and Connecticut, wished to see that contest brought to a speedy and successful close. Therefore, all of those eleven commonwealths had a very real interest in wishing the decision accepted. The common good of all the member States of the Confederation aided the acceptance of the decision of the Trenton Inter-State Court.

The fact, however, that this case, involving the sovereignty to land claimed by two sovereign and member States of the Confederation which had 
been for many years a bone of contention between the two incipient Nations, was peacefully adjusted by the employment of judicial means, was a very great gain for the future of the Confederation. It was not merely that one more cause of future trouble for the United States of America was thus peacefully disposed of, but also it helped to educate the States and their peoples to look to jural rather than to armed means for deciding and disposing of differences between the several members of the Confederated States.

There were other cases of boundary disputes between the original colonies or States, among them those of South Carolina vs. Georgia, and Massachusetts vs. New York. In these two cases, Inter-State Courts, similar in form to the Trenton Tribunal which sat on the case of Pennsylvania vs. Connecticut, were appointed. But as constantly happens every day in suits started between individuals in the Municipal Courts, those cases were settled out of Court and did not come to trial. Likewise several other cases between two of the States were settled privately before Inter-State Courts had been appointed according to the ninth article of the Articles of Confederation. ${ }^{27}$

${ }^{27}{ }_{13}$ U United States Supreme Court Reports. 


\section{PART II.}

In the course of a few years' experience under the Articles of Confederation, however, it was found that a more perfect bond of union between the thirteen States was necessary unless the United States of America were to divide either into several groups or to return to their original thirteen component parts. Accordingly, a Federal Convention was called, to which all the States were asked to send delegates. It sat in Philadelphia in 1787. After much discussion behind closed doors, it elaborated a fundamental written law or compact which was submitted to the several States for their acceptance or rejection. Probably the most original provision of the new form of government was that for the first time in history it was proposed to establish side by side with the local sovereignty another sovereignty which should extend over all the area of the local sovereignties. The inhabitants were to be endowed with a double allegiance and citizenship; those which they owed to and obtained from the individual State in which they lived, and a new allegiance and citizenship which they would owe and obtain from the new State whose extent would 
be co-extensive with the total area of all the individual thirteen States combined.

Another innovation in government embodied in the proposed new American Constitution, was the creation of a Supreme Court for the new Federal State which was not to be subject either to the legislative or executive branches of the government, but was to be co-equal with them. While the plan of an independent judicial power was now to be put into actual practice for the first time in history, the idea nevertheless was not new in 1787 . The germ of this idea may have been started before 1748 , but at any rate it was clearly formulated in that year in l'Esprit des Lois by Montesquieu, published at Geneva. This much cited and talked of but apparently now little read passage of Montesquieu is as follows: "There is no liberty if the power to judge is not separated from the legislative and the executive powers. If it were joined to the legislative power, the authority over the life and liberty of citizens would be an arbitrary one, for the judge would be legislator. If it were joined to the executive power, the judge might have the power of an oppressor." 28 Montesquieu was one of the pub-

${ }^{28}$ The original French text is as follows:- "Il n'y a point encore de liberté si la puissance de juger n'est pas separée de la puissance 
licists whose works were known to and consulted by the members of the Federal Convention of I787. In addition, however, the conception of a Federal Supreme Court originated, as we have seen, in part in the history of the thirteen colonies. In other words, the Federal Constitution grew in part out of the relations that developed in the colonial period between the colonies themselves and between them and the mother country.

A motion was made by Dickinson of Pennsylvania during the debates in the Federal Convention making the judges removable by the executive upon the application of both the Senate and the House of Representatives. In other words, the motion proposed a recall of the judges by the joint action of the Congress and the President. John Rutledge of South Carolina opposed the motion on the ground that such a proposition was incompatible with the plan of giving the Federal Supreme Court the right to judge between the United States and the individual States, or between two or more individual States. The motion was lost. ${ }^{29}$

législative et de l'executrice. Si elle était jointe à la puissance législative, le pouvoir sur la vie et la liberté des citoyens serait arbitraire; car le juge serait législateur. Si elle était jointe à la puissance executrice, le juge pourrait avoir la force d'un oppresseur."

${ }^{29}$ Max Farrand: The Records of the Federal Convention of 1787 , New Haven, I9II, Volume II., page 428. 
In some of the States, notably Virginia and New York, there was much objection to ratifying the new form of general government, and much of the opposition to adopting the new form of government was because of the powers with which the proposed Supreme Court of the United States was to be clothed.

However, the Constitution, which provided for a Supreme Court of the United States that would be independent of and on a par with the executive and legislative branches of the government of the new Nation that it was proposed to create, was finally ratified and accepted by all of the thirteen member Nations of the Confederation.

A hitch to the easy acceptance by the member States of the Union of the United States Supreme Court sitting in judgment as a Supreme Tribunal over all the individual States soon occurred. In the celebrated case of Chisholm vs. Georgia, ${ }^{30}$ one of the earliest cases brought to the bar of the newly constituted Court, a citizen of South Carolina sued the State of Georgia. The case came on for a hearing only in February term, 1793, expressly to give the State of Georgia ample time to decide what she would do in the matter. Through counsel,

${ }^{30}{ }_{2}$ Dallas, page 4 rg. 
Georgia presented a remonstrance against such a suit being entertained by the Court, but took no further part in the case. Randolph, the AttorneyGeneral of the United States, argued the right of the plaintiff in the case, to bring the suit. The members of the Tribunal gave separate opinions.

Chief Justice Jay in his opinion stated the question at issue with great clearness. He said: "The question we are now to decide has been accurately stated, viz.: Is a State suable by individual citizens of another State? It is said that Georgia refuses to appear and answer to the Plaintiff in this action, because she is a sovereign State, and therefore not liable to such action." $\mathrm{He}$ held that a State of the Union was suable by a citizen of another State. With him agreed Justices Blair, Wilson and Cushing, while Justice Iredell was opposed to a construction of the Constitution which would "admit, under any circumstances, a compulsive suit against a State for the recovery of money."

The Court ordered the plaintiff to file his declaration, copies of which were to be served by the Tribunal on the Governor and the AttorneyGeneral of Georgia by or before the following June, and that unless the State appeared or showed 
cause to the contrary to the Court by the first day of the next term, judgment by default would be entered against the State of Georgia.

As none of the other States of the Union, however, relished the idea of being brought as Georgia had been, to the bar of the United States Supreme Court by a citizen of another State, the eleventh amendment to the Federal Constitution, expressly to overcome for the future the results of that decision, was added in January, 1798, having been on the eighth of that month ratified by three-fourths of the States of the Union. That amendment prohibited the judicial power of the United States entertaining suits begun against a State of the Union by the citizens of another State or by the citizens of a foreign State. The writ of enquiry awarded to the plaintiff in Chisholm vs. Georgia was not sued out, and so that cause as well as all other suits by individuals against States that were pending, were swept away from the records of the Court by the eleventh amendment to the Federal Constitution "agreeably to the unanimous determination of the Judges, in Hollingsworth et al. vs. Virginia, argued at February term, 1798." It is altogether probable that the authorities of South Carolina persuaded Chisholm, a South Carolinian, 
not to sue out the writ under the decision in Chisholm vs. Georgia.

When the Supreme Court of the United States was organized under the Constitution, with John Jay of New York as Chief Justice and four associate Justices, at first it had not much to do. However, slowly, cases came to its bar, and it asserted, with John Marshall as its Chief Justice, its right to exist as a separate and co-ordinate branch of the Government by the side of the Legislative (Congress) and the Executive (President) departments. The Court decided whether the laws passed by the Congress were legal under the Constitution, and so whether it was lawful for the President or Executive department to carry such laws into effect, or whether they were void according to the spirit and meaning of the Constitution and so of no avail.

In the famous case of Marbury vs. Madison, Chief Justice Marshall, in delivering the opinion of the Supreme Court, gave a clear and lucid exposition of the juxtaposition of the three great departments of government to one another within the meaning of the Constitution. He said: $:^{31}$

"The powers of the legislature are defined, and limited; and that these limits may not be mistaken,

${ }^{31}$ I Cranch, United States Supreme Court Reports, page I 76. 
or forgotten, the Constitution is written. To what purpose are powers limited, and to what purpose is that limitation committed to writing, if these limits may, at any time, be passed by those intended to be restrained? The distinction, between a government with limited and unlimited powers, is abolished, if those limits do not confine the person on whom they are imposed, and if acts prohibited and acts allowed, are of equal obligation. It is a proposition too plain to be contested, that the constitution controls any legislative act repugnant to it; or, that the legislature may alter the constitution by an ordinary act.

"Between these alternatives there is no middle ground. The constitution is either a superior, paramount law, unchangeable by ordinary means, or it is on a level with ordinary legislative acts, and like other acts, is alterable when the legislature shall please to alter it.

"If the former part of the alternative be true, then a legislative act contrary to the constitution is not law; if the latter part be true, then written constitutions are absurd attempts on the part of the people, to limit a power, in its own nature illimitable."

The Federal courts have the right and it is their duty to judge whether laws passed by Congress are constitutional or not. 
Marshall ended by saying "that a law repugnant to the constitution is void; and that courts, as well as other departments, are bound by that instrument." 32

A custom had grown up and existed, as we have seen, among the English-speaking North American colonies of sending their boundary disputes across the Atlantic for final settlement to the home government, an authority which was supreme over all the colonies as well as independent of them until the colonies began in $\mathbf{1 7 7 5}$ their revolt, which resulted in the winning of their complete independence. In that manner, gradually the ground was prepared for the creation, under the Articles of Confederation of the United States of America, for the setting up ad hoc of Inter-State Tribunals, and subsequently, under the Constitution of 1789 , the establishment of a Supreme Federal Tribunal which should be independent of the other co-ordinate branches of the proposed new Federal Government and also empowered to judge the legality or constitutionality of the laws which the legislative body of the new government might enact or the manner in which the executive branch of that government might attempt

${ }^{32}$ I Cranch, United States Supreme Court Reports, page I80. 
to execute those laws, as well as to judge between the individual States.

In August term, I799, the State of New York brought suit in the Supreme Court of the United States against the State of Connecticut for the purpose of establishing the title of the former commonwealth to a tract of land which it claimed under an agreement entered into between New York and Connecticut on November 28th, 1683. The suit was to enforce the specific performance of the agreement. The case was settled without a decision being given on the legal merits of the controversy.

Of New York vs. Connecticut, Justice Baldwin in I 838 said it was held in 1799 "that though a State could not sue at law, for an incorporeal right, as that of sovereignty and jurisdiction, there was no reason why a remedy could not be had in equity."

It was not, however, apparently until more than a generation after the Tribunal was instituted that a case of difference between two of the States of the Union was started on its way to the Supreme Federal Tribunal. New Jersey and New York disagreed as to their boundary line, and the former of those two States filed a bill in 1831 before the Supreme Court of the United States against the

${ }^{33}{ }_{3}$ Dallas, page $4^{1} 3$, for the original case. 
State of New York with the object of ascertaining and deciding the frontier line dividing the two commonwealths. ${ }^{34}$ The opinion of the Court was given by Chief Justice Marshall, and the Tribunal held that if after service of process had been made by New Jersey upon the Governor or AttorneyGeneral of New York, and the latter commonwealth had failed to respond within sixty days, New Jersey could appear, through her properly constituted legal representatives, before the Court and proceed $e x$ parte. Before the case came to a final decree, New York compromised the dispute with New Jersey to the satisfaction of the latter State, but the rule of procedure then established has since been followed.

Hardly had New Jersey and New York settled their frontier dispute out of court, than a new contested boundary case between two States was brought to the bar of the Federal Supreme Court.

It was in March, I832, that began the long drawn out and stoutly contested case of the State of Rhode Island and Providence Plantations, complainants, vs. the Commonwealth of Massachusetts, defendant. Rhode Island brought suit on March 16th, 1832, in

${ }^{34}$ New Jersey vs. New York, 5 Peters; United States Supreme Court Reports, I831, page 284 . 
the Supreme Court of the United States, against Massachusetts in order to have the boundary or frontier line between the two commonwealths settled by a judicial decision..$^{35}$ The case was not finally decided until January, I 846. Daniel Webster was the leading counsel for Massachusetts and Mr. Hazard for Rhode Island. The two States claimed the land in dispute under various royal charters granted by the Crown of England. Rhode Island also advanced a right in virtue of grants from the Indians. Controversies existed over the boundary between the two colonies at an early period in their history. The contention between the two States was whether a line run in 1642 by two surveyors, named Woodward and Saffrey, was the true divisional line between the two commonwealths as Massachusetts claimed, or whether it should be moved about four miles further north as Rhode Island contended. As Massachusetts was in possession of the territory in dispute, Rhode Island appealed as complainants to the equity side of the Court that "the northern boundary line between the complainants and the State of Massachusetts may,

${ }^{35}$ The Uniled States Supreme Court Reports, I 2 Peters, page 657; 13 Peters, page 23; 14 Peters, page 210; 15 Peters, page 233; 4 Howard, page $59 x$. 
by the order and decree of this honorable Court, be ascertained and established; and that the rights of jurisdiction and sovereignty of the complainants" might be restored and confirmed to them. ${ }^{36}$

On the part of Massachusetts, it was pressed in the argument of counsel that the Court, under the Constitution, did not possess jurisdiction over all cases between the States but only "controversies;" and that a disputed boundary question, where sovereignty and not merely title was involved, lay outside of the jurisdiction of the Tribunal.

At the January term, I838, of the Court, Justice Baldwin delivering the opinion of the Tribunal, held that the word "controversies" applied to all disputes or controversies between the States, and that consequently the Court had jurisdiction in the case at bar. Referring to the argument urged on behalf of Massachusetts that the controversy was a political and not a judicial question, Justice Baldwin said: "It is said, that this is a political, not a civil controversy between the parties; and so not within the Constitution, or thirteenth section of the judiciary act." In the view of the Court, the controversy was over either the locality of a point three miles south of a certain river, or whether a certain point was the

${ }^{36} 2$ Peters, United States Supreme Court Reports, page 665. 
"true point from which to run an east and west line," as the agreed boundary between the two colonies or States. "In the first aspect of the cases, it depends on a fact; in the second, on the law of equity, whether the agreement is void or valid: neither of which present a political controversy, but one of an ordinary judicial nature, of frequent occurrence in suits between individuals. This controversy, then, cannot be a political one." The Court, therefore, decided against the plea of Massachusetts that the Tribunal had not jurisdiction according to the grant of the Constitution, and the case went on to be tried on the merits of the proper location of the frontier between the two States which had appeared through counsel before the bar of the Supreme Court.

From this ruling the Chief Justice of the 'Tribunal, Roger Brooke Taney, dissented. He held that the case was political, not judicial, in character, and that the Court did not have jurisdiction.

"The powers given to the Courts of the United States by the Constitution," that great Judge said, "are judicial powers; and extend to those subjects, only, which are judicial in their character; and not to those which are political.

"Contests for rights of sovereignty and jurisdiction between States over any particular territory, are not, 
in my judgment, the subject of judicial cognizance and control, to be recovered and enforced in an ordinary suit; and are, therefore, not within the grant of judicial power contained in the Constitution."

The Supreme Court of the United States having determined that it possessed the right to decide the difference between Rhode Island and Massachusetts concerning the boundary or frontier that separated their respective territories over which they could exercise and maintain sovereign authority, the case was thereafter argued by the most eminent of counsel upon the merits of the boundary question itself before the Court. Finally at January term, I846, the Court, Justice McLean delivering the opinion of the Tribunal, sustained the contention of Massachusetts as to the possession of the long strip of territory over which the dispute had arisen between the two States. A disagreement, which had lasted between two Commonwealths for well over a century, was thus peacefully settled by a judicial decision based upon legal grounds. A great precedent and step forward was thus established in the settlement of disputes between the member States of the North American Union by judicial decisions instead of by an appeal to armed combat. 
As the first great question decided by the United States Supreme Court between two of the member States of the North American Union, the case of Rhode Island vs. Massachusetts may, in some important respects, be compared in the sphere of the United States of America, with the submission of the Alabama Claims case to the Geneva Tribunal, the first regularly constituted International Judicial Tribunal, in the domain of the family of Nations.

Following the final settlement by the Court of the contention between Rhode Island and Massachusetts over the proper location of the divisional line between those two commonwealths, other disputed frontier cases between two of the member States of the Union were brought to the bar of the Federal Supreme Court for final decision and settlement.

Then there began to be referred for settlement to that high Court an increasingly long list of cases of disagreement between two of the member States of the Union. These cases have involved matters of various interest. 


\section{PART III.}

In January term, I849, a dispute over the northern boundary of the State of Missouri and the southern line of the State of Iowa was tried by the Supreme Court of the United States. ${ }^{37}$ The opinion turned upon the proper interpretation of some treaties between the United States Government and some Indian tribes, the Great and the Little Osage Nations, and the existence of certain alleged rapids in the Des Moines River.

Ten years later the State of Alabama brought suit in the Supreme Federal Tribunal against her sister State, Georgia, over their mutual boundary line. ${ }^{38}$ Alabama claimed to low water on the western bank of the Chattahoochee River, while Georgia asserted her sovereignty extended to high water on the western side of the river. The decision turned in part upon the definition of what was meant by the word "River."

In 1870 the same high Court tried the con-

${ }^{37}$ Missouri vs. Iowa: 7 Howard's United States Supreme Court Reports, page 660.

38 The State of Alabama vs. the State of Georgia: 23 Howard's United States Supreme Court Reports, 1859, page 505. 
troversy between the States of Missouri and Kentucky over the possession of Wolf Island in the Mississippi. ${ }^{39}$ After a careful consideration of the evidence adduced by the two States, the judgment of the Tribunal was in favor of Kentucky.

In I 889 Indiana brought a suit in equity against Kentucky "to settle and determine the boundary line between" the two States. ${ }^{40}$ The dispute was over the possession of an island on the north side of the Ohio River, about five miles long and more than a mile wide, with an area of about two thousand acres. In defense to the suit of Indiana, Kentucky claimed that Virginia had passed an Act in 1783 in her legislature whereby Virginia empowered her delegates in Congress to convey to the United States all Virginia's rights "to the territory or tract of country within the limits of the Virginia charter, situate, lying and being to the northwest of the river Ohio." Kentucky further asserted that on March Ist, 1784, the delegates of Virginia in the Congress of the Confederation executed a formal deed giving to the United States all the rights of

${ }^{39}$ Missouri vs. Kentucky: II Wallace's Uniled Stales Supreme Court Reports, 1870, page 395.

${ }^{40}$ Indiana vs. Kentucky: 136 Uniled States Supreme Court Reports, 1889, page I. 
sovereignty, etc., of Virginia in the territory "situate lying and being to the northwest of the Ohio." Indiana was admitted as a State of the United States many years subsequently to the admission of Kentucky as a State. The opinion of the Tribunal was in favor of Kentucky.

The boundary case of Virginia vs. Tennessee was heard in 1892 and decided in $1893 .^{41}$ The judgment of the Tribunal gave an exhaustive historical review of the claims advanced by the two contending States, and looked at the case from many points of view. In reference to prescription, quotations were given in the opinion from such well known writers on the Law between Nations as Vattel and Wharton. The judgment was in favor of the claims of Tennessee.

In 1904, the Federal Supreme Court handed down a decision in the case of Missouri vs. Nebraska. ${ }^{42}$ The facts briefly were as follows. From the time the two States were admitted into the Union until I867, the course of the Missouri River where it was the boundary between the two States had

${ }^{41}$ Virginia vs. Tennessee: 148 United States Supreme Court Reports, page 503 .

${ }^{42}$ Missouri vs. Nebraska: 196 United States Supreme Court Reports, I904, page 23. 
changed its course by only such variations as naturally followed in the passage of time from one side of the stream to the other. But on July 5 th, I867, within a period of twenty-four hours and during a flood, the river which up to that time for years back had passed round McKissick's Island, cut for itself a new channel about half a mile wide across land which then belonged to Nebraska. After this change in the course of the river, the Missouri ceased flowing round McKissick's Island, the old channel dried up and this sudden change in the course of the river became permanent. As a consequence, land which before this change in the Missouri's course was west of the river, thereafter was east of the river. Did this sudden and continuing change in the course of the Missouri River make a change in the boundary line between the two States? The Tribunal held the boundary between Missouri and Nebraska was not changed but remained as it was before the avulsion and that the land in dispute continued to form part of Nebraska. In 1905, Chief Justice Fuller handed down the opinion of the Supreme Court of the United States in the frontier case of Louisiana vs. Mississippi. ${ }^{43}$

${ }^{43}$ Louisiana vs. Mississippi: 202 Uniled States Supreme Court Reports, 1905, page 1 . 
The two States clashed over their boundary, because they both wished to possess valuable oyster beds; and the oyster legislation of the two States led to a conflict between their respective authorities. The Court applied the doctrine of the thalweg to the case, saying that the word had been taken over into many languages. The Chief Justice referred in his opinion to the San Juan Water Frontier decision, the Alaskan Boundary case, and Lord Stowell's judgment in the case of The Anna (1805).

In 1908 in the case of Missouri vs. Kansas, the Supreme Federal Tribunal held that, notwithstanding the gradually changing position of the Missouri River, the middle of that stream was the proper boundary between the two States; and further that an island in the Missouri River lying west of its main channel as it then existed at the time the case was heard, belonged to Kansas, even though that same island was situated to the east of the original boundary line that divided the two States. ${ }^{44}$

The boundary case of Washington vs. Oregon, was decided in $1908 .{ }^{45}$ There were and are two

${ }^{44}$ Missouri vs. Kansas: 213 United States Supreme Court Reports r 908 , page 78 .

${ }^{45}$ Washington vs. Oregon: $2 \mathrm{II}$ United States Supreme Court Reports, 1908, page I27; ibid, Volume 214, page 205. 
channels at the entrance of the Columbia River. The act admitting Oregon as a State of the Union provided for a boundary passing through the middle of the north channel. Subsequently, the State of Washington, some years after its admission as a State, contended that the boundary should pass through the southern of the two channels, as it had then become the main or most important channel at the mouth of the Columbia River. The Court upheld the contention of Oregon.

The disputed frontier of Maryland vs. West Virginia was tried in 1909 by the Court sitting in Equity. ${ }^{46}$ In substance in this case the Tribunal decided that a boundary which has been accepted as the frontier for a century or so between two of the member States of the Union should be maintained for the future, even though it might not have been correctly run according to astronomical calculations.

The eleventh amendment to the United States Constitution provided that the judicial power of the United States should not extend to suits by private citizens against a member State of the Union..7

\footnotetext{
${ }^{46}$ Maryland vs. West Virginia: In Equity. 217 Uniled Slales Supreme Court Reports.

${ }^{47}$ New Hampshire vs. Louisiana and others: New York vs. Louisiana and others: 108 Uniled Slotes Supreme Court Reports, 1882,
} 
Nevertheless enterprising individuals attempted to bring such suits.

In 1882 some citizens of New Hampshire and New York, the owners of Louisiana State bonds upon which they could not collect the interest, tried, with the aid of their respective States, to assign their bonds to their respective States, with the object that the latter would bring suit in their own names. The two State Legislatures obligingly complied. The Supreme Court of the United States, however, held, that in view of the eleventh amendment a member State of the United States cannot create a controversy with a sister State by taking upon itself the recovery of debts owing to its own citizens by the other State.

The above plan having failed, some individuals who held about two hundred and fifty bonds of South Carolina upon which they were unable to recover, made an outright gift of ten of those bonds to the State of South Dakota. ${ }^{48}$ That State sued its sister State, and gained judgment

page 76. The eleventh amendment which went into effect January 8th, I798, reads: "The judicial power of the United States shall not be construed to extend to any suit in law or equity, commenced or prosecuted against one of the United States by citizens of another State, or by citizens and subjects of any foreign State."

${ }^{48}$ I08 United States Supreme Court Reports. 
for the ten bonds. ${ }^{49}$ But the Court held that the individuals were not helped thereby to recover about two hundred and forty other bonds. As to the right of South Dakota to recover, the Tribunal was divided. Five justices held that South Dakota could recover, while four were of the opinion that, in view of the eleventh amendment, she could not recover.

Questions of disputes arising between member States of the Union over the right to control the use of water courses have been submitted to and decided by the Federal Supreme Court. Such a case was that of Kansas vs. Colorado. ${ }^{50}$ In that case Kansas brought suit to enjoin Colorado from absorbing to the use of the inhabitants of the latter State the waters of the Arkansas River, which, taking its source in the Rocky Mountains in the State of Colorado, flows through Colorado on into the State of Kansas where it becomes a navigable stream suitable for the purposes of communication and commercial dealings. Kansas maintained that Colorado was using more

19 South Dakota vs. South Carolina: 192 United States Supreme Court Reports, 1903, page 286.

${ }^{80}$ State of Kansas vs. State of Colorado: 185 Uniled Sioles Supreme Court Reports, page 125; ibid, Volume 206, page 406. 
than her proper share of the waters of the Arkansas River for purposes of irrigation and in time would absorb it all and ruin the river for navigation in Kansas. The Tribunal sustained its jurisdiction in the case. On the merits, however, the decision was against Kansas, without prejudice either to another suit or to the Federal Government to preserve and control the rights of navigation.

Another case involving rights in water courses was the suit brought by Missouri against Illinois and the Sanitary District of Chicago. ${ }^{51}$ In this case the authorities of Chicago built a drainage canal from Lake Michigan to a river flowing into the Mississippi River. Their object was to have the sewage of Chicago, which formerly was ejected into Lake Michigan, thereafter carried off and discharged into the Mississippi River. The case was tried twice by the Court. On the first hearing the Court upheld the right of Missouri to bring suit because the construction of the canal might be a cause of danger to the well being of the people of Missouri. At the second trial of the case, the Tribunal held that Missouri had not made out a

${ }^{51}$ Missouri vs. Illinois and the Sanitary District of Chicago, 180 United States Supreme Court Reports, page 208; ibid, Volume 200, page 496. 
case that this drainage was dangerous to the health of her citizens.

The Federal Supreme Court has construed broadly its original jurisdiction in sustaining suits by States against the citizens of another State, thereby extending the ramifications leading to possible causes of conflict in the interests of two or more States over which the Court is the final judge or arbiter. For example in the case of Georgia vs. The Tennessee Copper Company, Georgia brought suit to restrain a copper company in Tennessee from discharging harmful gases from their works which were blown by the winds over the territory of Georgia to the detriment of property of some of the citizens of Georgia. ${ }^{52}$ The Court held that, as on "the evidence the pollution of the air and the magnitude of that pollution" were not open to question, after allowing the defendants a reasonable time to control the fumes, an injunction against their works would be issued.

In the case of Louisiana vs. Texas, however, jurisdiction was refused by the Tribunal on the ground that the case was rather a complaint of some individuals in New Orleans than a controversy

${ }^{82}$ Georgia vs. Tennessee Copper Company, 206 Uniled Stales Supreme Court Reports, 1906, page 236. 
between States. The suit was rather like a case of Private International Law between individuals instead of a case of Public International Law between States. ${ }^{53}$ And so the case of Louisiana was dismissed.

South Carolina vs. Georgia was the case of a bill in equity filed by South Carolina asking for an injunction restraining the State of Georgia, the Secretary of War of the United States, the Chief of the Corps of the United States Engineers, and their agents from "obstructing or interrupting" the navigation of the Savannah River, in violation of the compact entered into by the States of South Carolina and Georgia on April 24th, 1787. ${ }^{54}$ The Court decided that the power to regulate the navigation of the Savannah River had passed from the two States upon the adoption of the Constitution to the Federal Government.

In 1907, Virginia brought suit against West Virginia for a proper division of the debt of Virginia with West Virginia. ${ }^{55}$ Originally West Virginia when

${ }^{53}$ Louisiana vs. Texas: ${ }_{7} 6$ United States Supreme Court Reports, I899, page I.

${ }^{54}$ South Carolina vs. Georgia, 93 United States Supreme Court Reports, 1876, page 4 .

${ }^{55}$ Commonwealth of Virginia vs. State of West Virginia: 209 United States Supreme Court Reports, 1907, page 514 . 
she became a State had agreed to assume her proper proportion of the debt of Virginia as it stood in $186 \mathrm{I}$, but West Virginia had never carried her intention into effect. In 1908 the Federal Supreme Court upheld its jurisdiction in the case. In r9lo the suit was referred to a master and was then brought before the Court, which decided that West Virginia must assume her share of the debt in proportion to the basis of population and wealth in 1863 of what was the whole State of Virginia at the time when West Virginia broke off and became a separate State of the Union. The two States, however, were to attempt out of Court to decide the amount of the debt which West Virginia was to assume as her share, before asking the Court to decree the exact amount. $^{56}$

A review of the above cited cases shows that the highest Federal Court of the American Union has been called upon to decide, and has decided cases of disagreement between States of the Union that involved questions of boundary between the States; the regulation of water courses which, taking their rise in one State passed lower down in their course into and through the land of another Commonwealth;

${ }^{56}$ Commonwealth of Virginia vs. State of West Virginia: 220 Uniled Stales Supreme Court Reports, I9Ix, page I. 
the regulation of the discharge of sewage by one State so that one of her sister States complained that it was a detriment of the latter's interest; the enjoining of nuisances in neighboring commonwealths; finding out and apportioning in an equitable proportion public or State debts; and other subjects involving the interests of the inhabitants of two States.

\section{PART IV.}

While it is apparent from the many cases examined above that the United States Supreme Court has successfully decided and by its decisions settled in peace many controversies between two of the member States of the Union which otherwise might have resulted in war between the contestants, it must not be forgotten that all was not smooth sailing in the effort of the United States to prevent strife between its individual member States. A few cases of difference arose which threatened to bring on an armed contest between the United States and one of its member States; and one controversy at least almost precipitated an armed conflict between one of the member States of the 
Union and a Territory which was an applicant for full statehood within the Union.

In September, 1778, a British war vessel captured Gideon Olmstead of Connecticut and three other American fishermen near Cape Charles and took them to Jamaica. Placed there on the Sloop Active laden with a cargo of arms and other supplies for the British army, they were forced to aid in navigating the vessel to New York. One night the opportunity came to Olmstead and his three companions to seize possession of the vessel, whereupon they steered for Little Egg Harbor, New Jersey. When the Active was in full sight of the New Jersey coast, an armed brig equipped and commissioned by the State of Pennsylvania, the Convention, pursued and by force, against the protest of Olmstead, captured the Active, took her into the port of Philadelphia, and there Captain Thomas Houston of the brig claimed the Active as his prize of war. Another privateer, Le Gerard, which was in sight when the Convention took Olmstead and his prize, also claimed a share of the prize money as Le Gerard was acting in conjunction with the Convention. ${ }^{57}$

${ }^{87}$ Hampton L. Carson: The case of the Sloop "Active:" The Green Bag: Boston, 1895, Volume VII., page 17. 
The case was tried before Judge Ross, a signer of the Declaration of Independence, and a jury. The jury of the State Court decided that only one fourth of the prize money should go to Olmstead, while the remaining three fourths they divided between the State of Pennsylvania, the owners of the privateers, and the officers and crews of the Convention and Le Gerard. The Judge, who was bound by the local law which gave the jury the right to decide the facts, showed his sympathy for Olmstead and his associates. The latter promptly appealed to Congress.

By Congress, which was then sitting in the Pennsylvania State House, the case was referred to its standing Committee on Appeals, who called themselves "The Court of Commissions on Appeal for the United States of America." After hearing arguments and investigating, the Committee decided, September 15 th, I778, to reverse the State Court, directed the marshal of that Court to sell the sloop and cargo and, after deducting the cost, to pay the surplus to Olmstead and his friends. When Judge Ross, however, called on the marshal to pay the money into the Judge's hands, the Commissioners realized that they did not have the power at their backs to enable them to enforce their judgment. 
And so they said wisely they would wait until their powers as a Tribunal were more clearly defined.

"In the meantime," Mr. Hampton L. Carson has pointed out, "Judge Ross had, with great dignity and firmness, placed upon the records of his court a vindication of his action, alleging that after mature consideration he was of opinion that though the Court of Appeals had full authority to alter or set aside the decree of a Judge upon a pure question of law, yet there its power ended; that the verdict of the jury was made conclusive upon the facts without re-examination or appeal, under the terms of the State law erecting his tribunal, and he would submit to no usurpation of power."

On March 6th, 1779, Congress decided by a vote of $2 \mathrm{I}$ to 6 , the minority consisting of the five delegates from Pennsylvania and Witherspoon of New Jersey, that the Committee of Congress which had heard the appeal from the Pennsylvania Court in the case of Olmstead, had the power and was duly constituted to hear that appeal. On the other side the Legislative Assembly of Pennsylvania authorized Judge Ross to pay over the money which he received from the sale of the cargo and sloop to David Rittenhouse, the State Treasurer. 
Time passed, and the Constitution of the United States was composed in Philadelphia in the same Pennsylvania State House in which the Declaration of Independence was voted, and then the Constitution was ratified by the individual States, including Pennsylvania. Section two of article three of the new Constitution gave to the United States power over all cases of admiralty and maritime jurisdiction. The power of a new Nation was ready now to take cognizance of the case of Olmstead and his associates. Finally, after a number of years had passed, during which several inconclusive things happened, Olmstead appeared in 1803 before Judge Peters in the United States District Court at Philadelphia and obtained a decree against the daughters and executrices of Rittenhouse. Thereupon the Legislature of Pennsylvania passed an act requiring Rittenhouse's daughters to pay over the funds in dispute to the State Treasurer and requiring the Governor of the State to protect their persons and property. As Mr. Carson has shown the apparent contestants in the case were a man of seventy-six years and two women who had inherited the suit at law; but the real contestants were the Commonwealth of Pennsylvania and the United States of America. Nothing further was done by 
Judge Peters. In I 808 Olmstead appealed to the Supreme Court of the United States. Chief Justice Marshall issued a mandamus. In his opinion he said: "If the Legislature of the several States may at will annul the judgments of the Courts of the United States, and destroy the rights acquired under those judgments, the Constitution itself becomes a solemn mockery, and the Nation is deprived of the means of enforcing its laws by the instrumentality of its own tribunals. So fatal a result must be deprecated by all; and the people of Pennsylvania, not less than the citizens of every other State, must feel a deep interest in resisting principles so destructive of the Union and in averting consequences so fatal to themselves. $* * *$ The State of Pennsylvania can possess no Constitutional right to resist the legal process which may be directed in this case."

When in obedience to the mandamus granted by the United States Supreme Court, Judge Peters issued his writ, the marshal of the District Court found the house of Rittenhouse's daughters at Arch and North Seventh Streets, afterwards known as Fort Rittenhouse, surrounded by the State militia. Civil war seemed a possibility. The futility of one State of the Union standing up against the strength 
of all the others, however, was apparent, and in the end the counsel of the wise men of Pennsylvania prevailed, the State of Pennsylvania yielded to the Federal Government, and in the end Olmstead received his prize money.

A dispute which threatened about 1835 to break loose in war within the Union was the disagreement between the State of Ohio and the Territory of Michigan over the possession of a strip of land which included the port of Toledo on Lake Erie. ${ }^{58}$ In this case the Federal Supreme Court was not appealed to. As Michigan was still only a territory Congress had the power to settle the matter. There were important commercial interests at stake based on geographical grounds. Ohio especially wished the land in dispute on account of the harbor of Toledo at which one terminal of the Ohio-Maumee Canal was situated. Two railroads also were in process of building in Michigan to terminate at Toledo. In addition to the disputed territory, Michigan also desired admission as a State of the

${ }^{58}$ W. V. Way: The Facts and Historical Events of the Toledo War of 1835; Toledo, Ohio, 1869.-Arthur Meier Schlesinger: Basis of The Ohio-Michigan Boundary Dispute in The Ohio-Michigan Boundary, Ohio, r9ı6, Volume I., page 59 et seq.-Anna May Soule: The Southern and Western Boundaries of Michigan, in the Michigan Political Science Association Publications, Volume II., page 48r. 
Union. The contest which began to become acute in 1833 gradually became warmer, until by 1835 the armed forces of the State of Ohio and the Territory of Michigan faced each other. The weight of power was overwhelmingly with Ohio, for not only was her population much larger than that of Michigan, but also the States of Indiana and Illinois favored her contention, since if the decision was against Ohio, Michigan would very possibly claim that her southern frontier should be run farther south than was actually the case, thereby giving her land in the possession of Indiana and Illinois respectively. In addition, political considerations favored Ohio, as Ohio was a doubtful State, while Michigan was surely in favor of the Democratic Party. President Andrew Jackson told the Governor of Ohio he would use the forces of the United States against Ohio if she began war with Michigan, but he told the Governor at the same time that he would veto any act of Congress that admitted Michigan as a State before the boundary question was settled. In the end Michigan was admitted to the Union June 15 th, I836, but the territory in dispute was given by Congress to Ohio. As a quid pro quo to Michigan, Congress gave her valuable mineral lands in the peninsula between Lake Michigan and Lake 
Superior. The solution enacted by Congress was a compromise that satisfied in the end both parties and avoided bloodshed. The power arrayed against Michigan was so incomparably greater than that which she herself possessed that there was no alternative left to her but to bow before the Act of Congress which at the same time that it deprived Michigan of the land she desired to the southward, gave her ample territorial compensation in another direction and also admitted her to statehood in the Union. It was a clear case of a settlement by the application of superior force without any thought of appealing to a judicial Tribunal.

Only a few years before the outbreak of the Civil War, a clash occurred between the United States and the State of Wisconsin, when the whole country was aroused for or against slavery, over the enforcement of the Fugitive Slave Law. ${ }^{59}$ A citizen of Wisconsin, Sherman M. Booth, editor of The Wisconsin Free Democrat, on March IIth, 1854, aided the escape of a fugitive slave who was in the custody of the deputy marshal of the United States District Court. Held for trial by a commissioner

${ }^{59}$ Stephen V. Ableman vs. Sherman M. Booth, and the United States vs. Sherman M. Booth, 2 I Howard United States Supreme Court Reports, I858, page 506 . 
duly appointed by the United States District Court for Wisconsin, Booth sought the aid of the State Courts of Wisconsin, which undertook to annul and set aside the action of the United States District Court on the ground that the Fugitive Slave Law was unconstitutional and void. Eventually the local Federal Court condemned Booth. That judgment excited great indignation in Wisconsin, and eventually the State Supreme Court of Wisconsin for the second time released Booth upon a writ of habeas corpus. In March, 1857, the Supreme Court of the United States took jurisdiction in the case; and in $185^{8}$ at the December term of the Court, reversed the decision of the Supreme Court of the State of Wisconsin. The Wisconsin Legislature passed a personal liberty law, and in 1859 they adopted a strong protest against the action of the Federal Courts. The people of Wisconsin then elected Booth's attorney upon a State rights and anti-slavery platform to a place upon the Supreme Court of Wisconsin. Booth was arrested again in 1860 by a United States marshal, then rescued and subsequently again arrested. Eventually the threatening conflict over the slavery question growing out of the persistent refusal of the State of Wisconsin to bow to 
the decision of the Supreme Court of the United States was brought to an end by President Buchanan, towards the end of his administration, pardoning Booth. That action of the President of the United States while it closed the incident, did not alter the fact that the State of Wisconsin just on the eve of the Civil War had successfully resisted the actions of the United States Courts, thereby virtually flouting the decision of the Federal Supreme Tribunal.

\section{PART V.}

Before the Wisconsin case had started to add turmoil to the already troubled waters through which the American ship of state was sailing, a case at law had already been begun in one of the State Courts of Missouri that, by the final decision of the United States Supreme Court with which that case was supposed to be ended, was to insure the outbreak of the Civil War within the country.

It was in December, 1855, that the case of Dred Scott was brought to the bar of the Supreme Court of the United States of America. It was the most important case yet brought to that great Court for settlement. That case in its bearings and ramifi- 
cations went to the very heart of what had been for two generations the dominating political question of the North American Union-the slavery question.

When the Constitution was framed the differences of interest of the thirteen original States resulted in several compromises. Thus while the representation in the lower house of Congress was to be based upon the number of the population of each State, the representation in the upper house was to be two Senators from each State, ambassadors as they have been termed, representing sovereign commonwealths. Another compromise was made concerning the possession of the unsettled lands lying to the west of Pennsylvania and north of the Ohio River, which only some of the thirteen States possessed. It was agreed that the new Federal Government should hold the northwestern lands for the common good of all, so that the moneys obtained from the sale of those lands could be used to lighten the burdens incurred in waging the war for independence as well by the States which did not possess lands to the westward as those that did. A third subject that could only be arranged by compromise was the question of slavery. By 1787 it was clear that, owing to climatic conditions, economically the interests of the Northern and the 
Southern States in regard to slavery were not the same. And so provision was made that slavery should not be disturbed where it then existed. Further it was arranged that the Northwest Territory, that is the territory west of Pennsylvania and north of the Ohio River, should be free; while the land south of the Ohio River, reaching to the Mississippi River, should be slave. ${ }^{60}$ In that way the balance was kept evenly between the free and the slave States in the movement westward of the population of the original thirteen States.

In 1803, however, the United States purchased for fifteen millions of dollars from Napoleon, First Consul of France, the great territory of Louisiana. There existed no definite provision at the time the purchase was made as to whether the new territory should be wholly free or wholly slave, or if divided between freedom and slavery, how that division should be accomplished. After much bitterness had been engendered between the free and the slave sections of the country, through seventeen years of political strife, the matter was solved, as it was supposed at the time, by an agreement of concession

\footnotetext{
${ }^{60}$ That was before the time of the Louisiana purchase, when the western frontier of the United States was, except at the extreme north and the extreme south, the Mississippi River.
} 
on both sides. This agreement, which was made on March 6th, I820, has ever since been known as the Missouri Compromise. It provided that in the newly acquired territories west of the Mississippi River, all the territory north of an east and west line run at thirty-six degrees thirty minutes north latitude, should be free territory and all the territory south of that line slave territory, except that north of that line, the territory of the present State of Missouri should be considered as slave territory, and that Missouri should be admitted as a slave State. For a time that compromise served to put off what was christened later by Seward as the "irrepressible" struggle between freedom and slavery within the American Union.

With the passage of time, however, as a result of the efforts of the slave power to gain new lands to offset the future increase of the number and power of the free States towards the northwest, north of thirty-six degrees thirty minutes, Texas was annexed by the United States in $\mathbf{1} 845$, and after war with Mexico, California and New Mexico were taken in 1848. And then once again, two years later, just as thirty years before in 1820 by the Missouri Compromise, the threatening rivalry between the free and the slave States was adjusted by the Compromise of 1850 . By the latter agree- 
ment, largely the work of Henry Clay, the boundaries of Texas were enlarged westward at the expense of New Mexico; California, whose people wished to exclude slavery from their land, was admitted as a free State; while in the territory of New Mexico, out of which Arizona and other territories were subsequently carved, the question whether slavery should be established there or not was to be left to the subsequent decision of its inhabitants. ${ }^{61}$ Though the latitude of New Mexico placed her within the area of slavery, her altitude rendered the successful cultivation of cotton impossible. And it soon became known slavery could not be introduced into New Mexico, as slave labor could not be profitably employed there. Then when the slave States recognized that the new States that would be added to the Union in the territories to the north and west of the State of Missouri and west of the State of Texas would come in in the natural course of events as free States, the slave power next sought to extend slavery into the Louisiana Purchase, above the line of thirty-six degrees thirty minutes. And so as settlers from the free States in the north and from

${ }^{61}$ James Ford Rhodes: History of the United States from the Compromise of 1850 , New York, 1893, Volume I., Chapters I. and II.John Bach McMaster: A History of the People of the United States, New York, I9r3, Volume VIII., Chapter I. 
the slave States, especially Missouri, in the south, moved into and settled in the virgin lands west and northwest of Missouri, known as the Kansas and the Nebraska territories, the struggle for mastery between the free and the slave States again, about I854, became acute. For whichever side won the contest as to whether those two territories should come in as free or slave States, would probably gain the eventual mastery in the Union as a whole. ${ }^{62}$

In the midst of all this turmoil over the question of how far northward slavery should be extended within the Union, occurred the historically famous case of Dred Scott.

The facts of that case briefly were these:

Dred Scott was a negro male slave belonging in I 834 to Dr. Emerson, a surgeon of the United States army. In that year Dr. Emerson took Dred Scott with him from the State of Missouri to the military post at Rock Island in the State of Illinois to which the doctor was ordered, and held Dred Scott there as a slave until April or May, 1836. Then Dr. Emerson was ordered to

${ }^{62}$ James Ford Rhodes: History of the United States from the Compromise of 1850 , New York, 1893, Volume I., Chapter V., Volume II., Chapter VI.-John Bach McMaster: A Brief Hislory of the Uniled Slates, 1907, page 332, et seq.: A History of the People of the United States, New York, 1913, Volume VIII., Chapters XC., XCI. 
Fort Snelling on the west bank of the Mississippi River. Fort Snelling was situated within the territory known as Upper Louisiana, a part of the Louisiana purchase from France in 1803 , and at a point north of the latitude of thirty-six degrees thirty minutes north latitude, and north of the State of Missouri. Dred Scott remained at Fort Snelling as a slave with Dr. Emerson until I838.

Harriet was a female negro slave belonging in I 835 to Major Taliaferro of the United States Army. That same year Major Taliaferro was ordered to Fort Snelling, in the upper Louisiana territory, and he took Harriet there and kept her there as a slave until 1836 , when he sold her as a slave at Fort Snelling to Dr. Emerson, by whom she was kept as a slave until 1838 at the fort. In I836 Dred Scott and Harriet, with Dr. Emerson's assent, who was their mutual master, intermarried. Two children were the result of their union. The elder child, Eliza, was born on the steamer Gipsey on the Mississippi River at a point north of the northern line of the State of Missouri. The younger child, Lizzie, was born subsequently at the military post of Jefferson Barracks, within the State of Missouri. In 1838, Dr. Emerson took Dred Scott and Harriet his wife, together with their 
child Eliza from Fort Snelling to the State of Missouri where they resided until the suit brought by Dred Scott to obtain his freedom was instituted.

The case was first tried in the lower Court of the State of Missouri for St. Louis County, which gave its decision in favor of Dred Scott and his family having become free owing to their removal to the free territory above the line of thirty-six degrees thirty minutes north. The case then went in $185^{2}$ to the Supreme Court of the State of Missouri. Basing its decision on the ground that Scott's status at home, regardless of what it had been elsewhere, was settled by the law of Missouri, the Supreme Court of that State reversed the decision of the lower State Court. Then the late Dr. Emerson's widow, in order to avoid appearing in Court, made over the control of Scott to the executor of her husband's estate, John F. A. Sanford, of New York. ${ }^{e 3}$ Thereupon Scott brought suit against Sanford, his new master, in 1854 in the United States Circuit Court of Missouri, on the ground that the latter was a citizen of another State. Sanford defended the action on

w John Bach McMaster: A History of the People of the United Slates, New York, 1914, Volume VIII., page 278. 
the ground that as Scott was a slave, he had not been and could not be a citizen of the United States and consequently could not sue in one of their Courts. This plea the Circuit Court overruled; but it decided that the law of Missouri held good and that consequently, as the highest State Court of Missouri had decided Scott was a slave, and it was the practice of the Federal Courts to uphold the decisions of the highest State Courts in such matters, Scott's status was that of a slave.

Upon a writ of error, Scott then appealed the case to the Supreme Court of the United States. It was argued at the December term, I855; and because of the grave interests to the country at large involved in the case, the Court heard the case reargued in the December term, I856. ${ }^{64}$ Such was the importance of the case, that in addition to the opinion of the Court given by Chief Justice Taney, all of the other eight members of the Tribunal also gave their separate opinions. The decision of the Court held that Dred Scott was not

${ }^{64}$ Congressional Globe, 4oth Congress, 3rd Session, Appendix, page 2II, for statement of Ashley of Ohio.-Samuel Tyler, Memoir of Roger Brooke Taney, Baltimore, 1872, pages 383-384.-Works of James Buchanan, edited by John Bassett Moore, Philadelphia, I9ro, Volume X., page 106, foot-note to inaugural address. 
a citizen of Missouri according to the sense or meaning of the word "citizen" as used in the Constitution of the United States; that consequently for that reason the United States Circuit Court had not jurisdiction of the case, and so could not pronounce judgment upon it; that the decision of the Circuit Court, therefore, was reversed and the suit of Dred Scott in that Court should be dismissed. That part of the opinion, therefore, by upholding the decision of the Supreme Court of the State of Missouri, maintained the status of Dred Scott as a slave. In that way the immediate point at issue concerning Dred Scott and his family as to whether they were free or slave, was settled. And in the opinion of a large part of the people of the country, who formed the Republican Party, which had come into existence as a powerful political association expressly to resist the extension of slavery in the free States and free Territories, the decision of the Tribunal should have ended there.

Originally, in 1855, the Court had decided to avoid touching on the constitutionality of the Missouri Compromise. ${ }^{65}$ But of the minority of two justices, McLean in any case, and probably

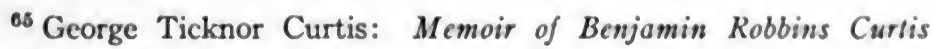
Boston, 1879, Volume I., page 180. 
Curtis, determined to review in their dissenting opinions the subject of negro slavery in the United States from the Free-Soil side of the question. ${ }^{66}$ McLean, whose name was before the Free-Soil Convention at Buffalo in 1848 , in connection with the Presidential nomination, had political aspirations for the Republican nomination for President to be held in Philadelphia in I856. In the Philadelphia convention Justice McLean received 196 votes as against 359 for General Fremont, who was chosen as the Presidential nominee. Justice McLean's intention to consider the slavery question in his opinion was a cause of uneasiness to the members of the Court who came from the slave States. The latter were in the majority, and after Buchanan's defeat of Fremont for the Presidency, had distinctly the stronger position. Although the members of the Court differed in opinion as to the extent of their jurisdiction on the record before them, yet in the end they all proceeded to review the slavery question so vital to the varied interests of the northern and the southern States, and gave

${ }^{66}$ Congressional Globe, 40 th Congress, 3 rd Session, Appendix, page 2II, for statement of Ashley of Ohio.-Works of James Buchanan, edited by John Bassett Moore, Philadelphia, r9ro, Volume X., page ro6, foot note to inaugural address. 
opinions touching the maintenance and spread of slavery from various angles. Six of the nine members of the Court decided that the Missouri Compromise of 1820 was not constitutional and therefore void and of no force, and consequently Dred Scott and the other three members of his family did not become free because of their having been taken to the territory north of thirty-six degrees thirty minutes. As to the contention that Dred Scott became free upon being taken into the free State of Illinois, the Court, in the words of its distinguished Chief Justice, held that as "Scott was a slave when taken into the State of Illinois by his owner, and was there held as such and brought back in that character, his status, as free or slave, depended on the laws of Missouri and not of Illinois." Five of the Judges declared that slaves were property, and that their status as such was recognized by the Federal Constitution and that they did not differ from other property. Consequently, that the owners of slaves could take their property in slaves into any of the Territories of the United States and keep them there as slaves. Four were of the opinion that the power granted by the Constitution to Congress to make rules and regulations for the territory of the United 
States did not apply to the territory acquired after the ratification of the Constitution of the United States. In the language of the Chief Justice: "It [the Constitution] does not speak of any territory, nor of Territories, but uses language which, according to its legitimate meaning, points to a particular thing. The power is given in relation only to the territory of the United States-that is, to a territory of the United States." In addition, three members of the Court decided that the validity of the Ordinance of 1787 , prohibiting the introduction of slavery into the territory north of the Ohio River and stretching from Pennsylvania to the Mississippi River in the west and to the great lakes in the north, ended when the Confederation ceased to exist upon the ratification of the Constitution and the creation of the new Nation of the United States of America. From the opinion of the Court, two justices dissented. They both upheld the constitutionality of the Ordinance of 1787 and the Missouri Compromise which prevented the introduction of slavery north of the Ohio River and of the line of thirtysix degrees thirty minutes north to the west of the State of Missouri. The net result of the judgment was not only to declare that Dred Scott and his 
family were still slaves, but also to practically open all the free Territories and free States to the institution of slavery.

By this decision the Supreme Court was attempting to decide in favor of the pro-slavery party the most fundamental difference of policy that had divided the country into two camps since before the Constitution was completed in $\mathbf{I} 787$ for presentation to the several States for ratification. In passing from the ground of legal questions, whether Dred Scott was still a slave after his return to Missouri, to the consideration of the area of political issues, whether the various compromises restricting slavery from being carried north of the Ohio River and north of the State of Missouri and beyond that north of thirty-six degrees thirty minutes were valid, or whether slavery could extend into the whole country, the Supreme Court was attempting to settle by a judicial decision, based ostensibly upon legal grounds, an economic difference of fundamental importance which could only be decided by a trial of actual strength. And that trial was made during the four years of Civil War from I86I to 1865 that desolated a large part of the country and destroyed much of its wealth and the lives of many of its inhabitants. That contest of four years of war 
reversed the decision of the Federal Supreme Court handed down four years before the war started.

All the machinery for arriving at a judicial settlement of differences between the American States had been provided for. The members of the Court were protected by a life tenure; they had learning, force of character, and experience. And by sitting and judging together, they had enhanced the judicial habit of their minds. Yet when they attempted in the Dred Scott case to decide a case that divided the States of the Union into two fairly even bodies over a question which went to the vitals of the economic life of each section, the Supreme Federal Tribunal miserably failed to prevent the Nation from being torn and racked for four years by Civil War. More than that, that high Court saw the decision, which it had arrived at by an overwhelming majority of the votes of its members, reversed and its findings brushed aside by war. In other words, its judgment was flouted by a majority alike of the States and the people.

Thus in actual practice the attempt of the Supreme Court of the United States to settle in peace by a judicial decision, according to the provisions of the United States Constitution, the fundamental economic difference of interest over 
slavery between the States north and those south of Mason and Dixon's Line, proved a complete failure. The Court had successfully settled by its decisions many differences between two of the States of the Union. But when it tried in the same way to decide a disagreement in which all the States took a deep concern and over which they were divided into two large camps, with the weight of numbers leaning towards the North, but with the strategic advantage of geographical position with the South, the Court could not compass its object. And war was the only solution that remained for the slavery problem. As a result of the American Civil War, slavery was abolished in the United States, the Nation was consolidated into a powerful member of the family of Nations, and the Federal Supreme Court was able to resume the even tenor of its way in settling successfully by judicial decisions according to the legal evidence submitted to it the differences that have occasionally arisen since between two of the member States of the Union as had been its wont from the settlement of the great case of Rhode Island and Providence Plantations vs. Massachusetts until the Court attempted and failed to decide the slavery problem in the Dred Scott case. 


\section{PART VI.}

If the foregoing course of events leading up to the formation and development of the United States Supreme Court are compared with the efforts of the Nations to develop international justice as a substitute for international war, some resemblances and some differences are found.

In both the spheres of the Confederation of the thirteen British North American colonies and afterwards of their successor, the more modern North American Union, as well as for a much longer time back in the greater sphere of the world as a whole, there has been a continuous, though until recently slow, growing desire to substitute as far as possible justice instead of armed strife in settling the differences between large communities.

If the beginning and development of judicial settlements in North America as a substitute for war, first in the time of the colonies and afterwards in the lifetime of the United States of America, is compared with the beginning and development of international justice in settling the differences that arise between Nations, many analogous features and marks of resemblance are found in the two cases. 
At the time the idea of judicial justice as a way of avoiding war-which had been in use among the Greek City States and also in Europe during the Middle Ages ${ }^{67}$ - began to develop in a halting manner in the North American colonies by the reference in I650 of the differences existing between the Dutch colony of New Netherland and the two English colonies of Connecticut and New Haven to a board of adjudication, the idea of international arbitration as a way of settling differences between two Powers or Potentates was likewise beginning again to take practical shape in Europe. In the treaty of Westminster in 1655 between France and England, those two Powers, possibly at the instigation of Oliver Cromwell, agreed that some minor differences that still existed between them should be referred for settlement in the first instance to a Board of Adjudication, and that body failing to settle the matters in dispute, that then those troubles should be submitted to the Imperial Free City of Hamburg for final judgment.

${ }^{67}$ Victor Berard: De arbitrio inter liberas Gracorum civitaies, Paris, 1894. -W. L. Westermann: Interstate Arbitration in Antiquily, The Classical Journal, Chicago, March, 1907.-Thomas Willing Balch: L'Evolution de l'Arbitrage International, Philadelphia, rgo8.-A. Raeder: L'Arbitrage International chez les Hellenes, Christiania, I912. 
Then the idea of a supreme judicial power to judge between the English North American continental colonies developed through the practice of appealing the unsettled disputes which arose between those colonies to the King in Council for judgment on the merits of each case, and thereby prepared the ground for the subsequent development of the Inter-State Tribunals in the time of the Confederation of the American States and the still later establishment of the Federal Supreme Court. Likewise, international justice as a practical means of avoiding war, from the beginning it had taken in Europe in the treaty of Westminster of 1655 , took a step in advance, in the provisions agreed on in the V., VI., and VII. articles of Jay's Treaty of I794 with Great Britain to submit various outstanding differences between the United States and Great Britain to boards of commissioners. And later still again international justice pressed forward when it blossomed out into the International Court of Justice which sat at Geneva in 1871-72, and by a judicial settlement decided the Alabama Claims without the spilling of a drop of blood.

In the Wyoming Valley, the Alabama Claims and the Bering Sea Fur Seal cases, the Tribunal that tried each case was appointed only to try the one 
case, and in each of those instances it was constituted ad hoc. Nevertheless, in all of those three trials the Court that heard the case, whether it was the Tribunal that sat at Trenton, or later the one at Geneva or still later the third Court that sat at Paris, in each instance was a Tribunal of Justice, by whatever name it may have been designated at the time, that tried the single case presented to its individual bar, and according to the evidence submitted to it gave a judgment based upon the law applicable to the particular case it had to consider.

Further, a comparison of the Inter-State Court that sat at Trenton in $\mathbf{I} 782$ with the International Courts of Arbitration or Justice which have sat at The Hague under the provisions of the First and the Second Hague Peace Conferences, such as the Court that tried the Casablanca Affair and the Tribunal that tried the North Atlantic Fisheries case, show another point of similarity in the development of substituting legal justice for war between sovereign communities as between the member States of the American Union in the one instance and between the Nations of the world in the other. The Trenton Court and the more recent Hague International Courts were all called into 
being under a general provision for the appointment of such Tribunals, in the one case under the ninth article of the Articles of Confederation of the United States, and in the other under the provisions of the agreements of the First and the Second Hague Peace Conferences.

Consequently, in considering the possibilities of developing the idea of International Tribunals set up ad hoc to try individual cases arising between Nations into one Supreme Court of the World, with a total of, for example, fifteen judges, sitting at The Hague in judgment upon the Nations of the world, it is well to ponder over the road the Supreme Court of the United States has had to travel to reach the exalted regard in which it has been held by all classes until very recently in the American Union; and also to consider the recent unfavorable criticisms and political attacks that have been made upon it and other American Courts by a substantial section of the American people.

When the thirteen British North American Colonies revolted against the mother land, they became allies spontaneously through the exigencies demanded by their efforts to gain and maintain by means of war their independence as thirteen sovereign Nations. But before the close of the 
struggle they found it necessary to enter into a formal written agreement, known as the Articles of Confederation, in order to bind themselves with one another more firmly than they were by the mere fact that they were working together for the common object of forcing Great Britain to acknowledge their right to govern themselves in peace and independently of her interference or control. And to preclude as far as possible the possibility of the newly born thirteen members of the family of Nations from falling on one another's throats, over disputes concerning land, boundaries and other causes, they provided a way for establishing a judicial machinery for trying such cases of difference between the member States of the Confederation. They agreed that any member of the Confederation which had a cause of dispute with one of her sister Commonwealths, could ask that the question of difference should be submitted to a judicial settlement. And before the war closed, the manner for establishing an Inter-State Tribunal as provided for by the ninth article of the Articles of Confederation, was invoked by the richest and probably the most powerful of the States at that time, in a case against another, though less powerful, member of the Confederation. 
Had the thirteen original States come into being without any fear of outside attack, it is very probable that they would not have agreed on any scheme such as was evolved in the ninth article of the Articles of Confederation. But the fear of the power of Great Britain, against which the thirteen colonies or States were battling for their independence, compelled them to adjust and compose the causes of difference between themselves in peace and concord; and so they were forced to seek a way by which their dissensions could be settled by a series of Tribunals that would decide according to the principles of justice. The necessity for presenting a united and harmonious front to Great Britain during the struggle for political independence, and afterwards to the world at large, was the sanction behind the Trenton Inter-State Tribunal which judged between Pennsylvania and Connecticut in the Wyoming Valley controversy.

When, by the Treaty of Paris of 1783 , the colonies had secured peace with Great Britain, and so were at peace with all the outside world, they soon found out that the loose Confederation in which they were bound did not hold them very tightly and that there was danger 
that it might break into pieces. As even united they were none too strong in comparison with the European Powers of that day, the thirteen Nations composing the United States of America were compelled through their fear of the outside world to suppress their jealousies of one another, which otherwise doubtless, sooner or later, would have broken up the Confederation; and to devise a scheme to form a more complete and perfect union. Accordingly, for that purpose, they formed and agreed to the compact known as the Constitution. To accomplish that object, the various States had to mutually give and take of the various provisions which individually they would have wished to see incorporated into the Constitution. For example, to meet the fear of the States of small area, who feared that in the new form of government they would be over-ridden by the large States if the members of Congress should be elected according to the number of the population throughout, it was agreed by the large States that in the Senate or upper house, the basis of representation of the States should be equal, that is, that each State should be entitled to elect two Senators. In the lower chamber, or House of Representatives, however, in order to meet the wishes of the large States for 
representation commensurate with the number of their people, the Representatives were to be elected on the basis of population. And other compromises to meet the demands and needs of various more or less clashing interests were compassed in the creation of the Constitution. In order to interpret the Constitution thus elaborated, and to decide how and in what manner, as a fundamental law, it held in check the Legislative and the Executive departments of the new Federal Government which it was proposed to create through the means of this Constitution side by side with the thirteen State Governments then existing, it was decided to establish a high and supreme Federal Court. In order to insure that the new Court, so far as human attributes made it possible, should be free of political bias and fear, and so the more likely in all its decisions, whether over matters of small import or those of the gravest consequence, to reach its conclusions upon strictly legal grounds and the principles of justice and equity instead of compromise, it was arranged that the Supreme Court of the United States, as the resulting Supreme Federal Tribunal has been known to all the world, should be co-equal with and absolutely independent of the Legislative and the Executive branches of the Government. There was 
much opposition at the time to the creation of such a Court. The fear was plain that it would impugn on the sovereignty of the individual States or Nations of the Confederation.

Nevertheless, the dread which the thirteen young States had of the interference among them of outside Powers was greater than the jealousy that they entertained of one another. The fear that they entertained of other outside Nations was strong and real enough to induce them to enter the proposed new Union by accepting the Constitution. In some States, such as Virginia and New York especially, the opposition to the Constitution was keen. However, in the course of time all of the thirteen States accepted it and came into the Union. And where before there had been thirteen Nations joined in a defensive league, one new Nation was created. It was a new Nation which provided for and required of its citizens a double allegiance and loyalty. For the new Federal Government was placed around and alongside of, not over, the original State Governments, with restrictions upon the sovereign powers of the Federal Government, while other powers were reserved to the individual State Governments. This was a new and unique device in the development of human polity. The power to deal with 
foreign affairs, which is the supreme test of whether a political organism is international or not, was vested, however, entirely in the Federal Government.

Great pains were taken in moulding the Constitution to provide for the safeguarding of the sovereignty of the individual thirteen States, and subsequently, in the first ten amendments to the Constitution additional guarantees for the preservation of those local sovereignties were added. The necessity felt at first to strengthen the Federal power of the American Union by degrees led the Supreme Court of the United States under the Chief Justiceship of John Marshall (I80I-I835) to build up the power of the central or Federal government. And more especially under the stress of outside pressure caused by the contact of the United States of America with the other Nations of the world, though other contributory causes worked to the same end, the sovereignty reserved with so much care in the Constitution to the individual States has grown slowly but gradually and surely less. The diminution of this sovereignty of the individual States has not progressed at all times. At times, as for example, when Roger Brooke Taney (I836-1864) presided as Chief Justice over the Supreme Court 
of the country, the slow but certain march of events to subordinate more and more the individual States to the central Federal State has been checkedalways excepting the absolute control over foreign relations with which the Federal Government was clothed from the first-by the strict interpretation put upon the Constitution by the highest Federal Court. But sooner or later, the absorption by the Federal Government of the functions of government which were originally exercised by the individual States has been resumed. Until finally, with the passage of the sixteenth amendment to the Constitution, which gives to the Federal Government the right to impose an income tax on every individual in the United States, there was conferred upon the Federal Government a power of immediate contact with every individual in the country which eventually will enable it to destroy all but the shell of the power of government and sovereignty possessed originally by the individual States. As a result, Pennsylvania, New York and the other individual member States of the Union, will then have no more sovereign power than Calvados and the other departments of France, or Somersetshire and the other shires of England, or Hesse-Nassau and the other provinces of Prussia possess to-day. 
The gradual change that has tended slowly but surely to weld the United States from a Union of States into one large single State has been caused in great measure by the influence exerted in countless ways, both directly and indirectly, by the other Nations of the world in their contact for more than a century with the North American Republic. As the latter Power has come into closer, more direct, and more vital intercourse and interdependence with the other members of the family of Nations in all parts of the world, the member States of the North American Union have realized, both consciously and unconsciously, that they must draw closer together if they wished to maintain their position "in the Sun."

\section{PART VII.}

Turning now from the consideration of the manner in which the Supreme Court of the United States has succeeded as the Tribunal of last resort of the American Union in keeping, in large measure, the peace between the individual States of that Union, it will be valuable to consider, by the illumination of the light of its history, how far the setting up of a Supreme Court of the World is 
likely to succeed as an infallible way of eliminating war from the affairs of the family of Nations.

An examination of the relations of the members of the family of Nations to one another shows that concerning questions which do not involve the vital interests of a Nation, that is legal questions, the past resort to International Tribunals for settling differences between the Powers gives ample assurance that strong Nations as well as weak ones would appeal their differences and submit to the Supreme Court of the World, as they have submitted to the decisions of International Tribunals constituted ad hoc. ${ }^{\text {s }}$ It is better, in such legal cases, for a Nation to go before a Court and lose its cause, and so have to give way in an honorable manner to the demands of its opponent than to take the chances of war, or allow the difference to smoulder and lead to possible embarrassment at a future time.

It was largely, for example, because Great Britain could not afford to allow the Alabama Claims to develop hostility to itself in the United States if

${ }^{68}$ John Westlake: International Law, and edition, rgro, Volume I., pages 300 et seq. - Lassa Oppenheim: International Law, and edition, 1912, Volume II., pages 3-5.-Amos S. Hershey: Essentials of International Public Law, 19r2, page 321.-Thomas Willing Balch: Differends juridiques et politiques dans les rapports des nations, Reoue Générale de Droit International Public, Paris, 1914, page 137. 
those claims were not satisfied, that she agreed to submit them to the Geneva Tribunal. In that way the honor of both Nations was safeguarded, satisfaction was given to the United States for the grievances under which they were chafing, and opportunity was offered to promote more cordial relations between the two Powers. The underlying reason why British statesmen were anxious to remove the cause of discontent in the United States towards Great Britain by submitting the Alabama Claims for a judicial decision to the Geneva Tribunal, was the fact that there were other Powers, besides those two, in the World, and Great Britain wisely shaped her policy in that instance from a world wide point of view.

Suppose, however, that a Supreme Court of the World with a permanent or definite personnel is set up at The Hague, will there be a sufficient force of compulsion behind it to compel at all times all the Nations to submit to that august Tribunal all the disputes arising between two or more Nations that those Nations are not able to settle themselves by diplomatic means?

The advocates of a Supreme Court of the World - composed of a small number of jurists, with irrevocable life appointments, some of whom, per- 
haps all, would be sitting constantly at The Hague - have great hopes that from the breasts of such judges all national prejudices would be eliminated in the judgments they would hand down in such a Tribunal. And the advocates of such a Court further argue that because of the permanency of the judges in contradistinction with the temporary status of the members of an International Tribunal named ad hoc to try a single case, or series of similar cases, such a Court would hand down only judicial decisions, and that as a further result the Nations would have far greater faith in the rendering of judicial judgments instead of diplomatic compromises by such a Supreme Court of the World than they could have in International Courts set up ad hoc.

In the instructions given to the American delegation to the Second Hague Peace Conference in 1907, they were urged to work for the establishment of a Supreme Court of the Nations. These instructions read in part:

"If there could be a tribunal which would pass upon questions between Nations with the same impartial and impersonal judgment that the Supreme Court of the United States gives to questions arising between citizens of the different States, 
or between foreign citizens and the citizens of the United States, there can be no doubt that Nations would be much more ready to submit their controversies to its decision than they are now to take the chances of arbitration.

"It should be your effort to bring about in the Second Conference a development of The Hague Tribunal into a permanent tribunal composed of judges who are judicial officers and nothing else, who are paid adequate salaries, who have no other occupation, and who will devote their entire time to the trial and decision of international causes by judicial methods and under a sense of judicial responsibility. These judges should be selected from the different countries, that the different systems of law and procedure, and the principal languages shall be fairly represented. The court should be made of such dignity, consideration and rank that the best and ablest jurists would accept appointment to it, and that the whole world will have absolute confidence in its judgments."

In referring to the record of the Supreme Court of the United States as an example by analogy of how a Supreme Court of the World would work in practice, there is in those instructions a fundamental omission. It is perfectly true, as the 
instructions say, that the Supreme Court of the United States judges with absolute fairness between individual citizens of different States of the American Union, or between citizens of foreign countries and citizens of the United States. But in those same instructions no mention is made of the unique and far more important record of the United States Supreme Court in judging between the individual States of the Union, and especially of its judgment in the Dred Scott case, a judgment in which all the member States of the American Union were vitally interested.

It is precisely that part of the record of the Federal Supreme Court which the instructions to the American delegation of 1907 fail to mention that are the essential and valuable part of the useful and honorable career of that great Court in estimating how a Supreme Court of the Nations will work in actual practice. The problem which a Supreme Court of the World will have to face is altogether different from that part of the record of the United States Supreme Court in which it has given "impartial and impersonal judgment" merely between individual "citizens of the different States, or between foreign citizens and the citizens of the United States." The Municipal Courts of other countries 
have done as well as that. They have not only judged impartially between their own citizens, but also between their own citizens and foreigners. Thus, for instance, since the Great War began, the highest Court of Germany according to Professor Philip Marshall Brown of Princeton University, in judging a patent case involving the rights of a Frenchman actually fighting for France, protected the rights of the Frenchman. ${ }^{69}$ But that case did not involve the relative power of France and Germany vis-d-vis of one another.

Is there any strong likelihood that a Supreme Court of the World in judging between the Nations would give only judicial judgments based upon justice and avoid all diplomatic or political compromises so that Nations would much more readily take their differences to such a Tribunal than to the International Courts now established ad hoc according to The Hague agreement?

To begin with, much of the unfavorable criticism which has been aimed at some of the judgments handed down by International Courts named ad hoc has not been altogether disinterested. Certainly

${ }^{69}$ Philip Marshall Brown: International Administration; Proceedings of the American Philosophical Society, Philadelphia, I9I6, Volume LV., page 316. 
that may be said of the criticisms of the counsel of a defeated Nation or of a Nation which has not gained all that it claimed. The adverse criticism of the judgment of a Court by an advocate of one side or the other in the case should be taken, both as regards Municipal and International Courts, cum grano salis. And, indeed, many judgments handed down by Municipal Tribunals could be attacked as compromises with quite as much accuracy and plausibility as some of the judgments given by International Courts set up ad hoc, which some writers have attacked as being compromises.

The decision of the International Court that sat on the Venezuela boundary case, for example, has been criticised by some jurisconsults in having leaned too much towards Great Britain's contention in its decision. In the opinion of other learned publicists and jurisconsults, however, that decision was eminently a judicial judgment.

The judgment in the North Atlantic Coast Fisheries case in I910, however, would seem to have fallen below the high plane set by the Geneva Tribunal in 1872 and the Bering Sea Court in 1893 of handing down strictly judicial judgments. For the decision handed down by The Hague Court named ad hoc in 1910 to try the North American Fisheries 
case bears on its face many marks of a compromise. But inasmuch as the United States of America and the British Empire each had one of their nationals sitting in that Court, and, when in addition the fact that those two members of the Court, one an American, the other a Canadian, agreed entirely in the judgment handed down by the Tribunal, is taken into account, together with the provisions of the preliminary agreement (compromis) which the two governments negotiated to refer the case to one of The Hague International Courts for settlement, it would seem that the blame for the element of compromise which crept into the decision should rather be visited upon the two governments who arranged to refer the case to one of The Hague Courts than upon the members of that Court. For the treaty rather gives the impression that the two governments so arranged things beforehand that the Court could not well avoid the element of compromise entering its decision. And this seems all the more likely when it is remembered that the American member of the Court was a United States Federal Judge, who was accordingly well accustomed in co-operation with his brother judges in the United States Court in which he sat, to form and hand down judicial decisions, and that the representative of 
the British Empire on the Court was none other than the Chief Justice of Canada, also well versed in judicial procedure. One of the neutral members of that Hague Court would seem in the separate opinion which he filed, to have been largely influenced in his judgment as to the extent of the territorial character of the waters of large bays by the fact that at the mouth of the greatest river passing through his own country and contiguous with her coast, there is a bay of immense extent with an opening towards the ocean of more than one hundred miles in width. If, however, he had sat to hear that same fisheries case, not merely in one of The Hague International Tribunals appointed $a d$ hoc to try that one single case, but as a member of a continuous and ever existing Tribunal, such as the Supreme Court of the United States or the Cour de Cassation of France, with a life appointment and with that intimate knowledge of his fellow judges which comes only from the continuous contact that results from repeated and continual sitting with them on the same bench to try numerous and varied causes of contention, would he have been any the more free from the national bias that showed itself in his individual judgment? The individual judgments of the Chief Justice and the Justices of the Supreme 
Court of the United States in the case of Dred Scott would seem to give a negative answer to the foregoing query.

In the Dred Scott case, when the Federal Supreme Court was wrestling with the political question involved in the contest between the free and the slave States, as to where and how far the institution of slavery should be allowed to spread, the individual members of the Court were undoubtedly influenced by their individual political views and the section of the country from which they were appointed.

Thus the Chief Justice, Taney, a Marylanderand Maryland was a slave State-who had owned slaves himself, whose ancestors had owned slaves, and who was a strict constructionist in his view of interpreting the Federal Constitution, was besides a Democrat, and the Democratic Party had become the pro-slavery party of the Nation. Of the other five members of the Tribunal who likewise declared the Missouri Compromise unconstitutional four were citizens of slave States. Wayne came from Georgia, Campbell from Alabama, Catron from Tennessee and Daniel from Virginia, all four slave States which afterwards seceded from the Union. Justice Grier, the sixth member of the Court, who 
voted to declare the Missouri Compromise unconstitutional by concurring with Taney's opinion, while a citizen of a free State, Pennsylvania, was a Democrat in his bringing up and in his appointment to the bench. Pennsylvania was still at that time what it had been for many years before, a Democratic State, having cast in 1856 her electoral vote for James Buchanan, who was President of the United States when the judgment in the Dred Scott case was handed down. Indeed he was the only Pennsylvanian who had reached the Presidency. Buchanan, a firm defender of the slave power, repeatedly upheld, before the Dred Scott case came up for trial, in his speeches and public writings the constitutionality of the Missouri Compromise, while after the United States Supreme Court had pronounced in the Dred Scott case that compromise unconstitutional, thereby opening the territories north of thirty-six degrees thirty minutes to slavery, Buchanan said not a word in favor of the Missouri Compromise as had been his habit years before. ${ }^{70}$ On the contrary, the President, who was advised in advance of the decision

${ }^{70}$ The Works of James Buchanan, edited by John Bassett Moore, Philadelphia, Volume IV., page 28, Volume VII., pages 386-387, Volume X., page 459 et seq., Volume XI., page II. 
of the Court by two of its members, upheld the decision of the Court declaring the Missouri Compromise unconstitutional. ${ }^{71}$ And Buchanan used his great influence to persuade Grier, his fellow Pennsylvanian, to go on record against the constitutionality of the Missouri Compromise. ${ }^{72}$ Justice Nelson who held that Dred Scott remained a slave in Missouri on the ground that the State Law of Missouri decided the status of Scott, but who, while actually agreeing with the majority of the Court that the Missouri Compromise was unconstitutional, would not join in giving an opinion to that effect, was a Democrat in politics and came from New York, a free State. His opinion was in the nature of a compromise decision, in that he would not publicly express himself upon the question of the Missouri Compromise. The two dissenting members of the Tribunal were Justices McLean and Curtis. The former was from Ohio, a free State, was himself a Free-Soiler and in addition several times was a strong candidate for the Republican

${ }^{71}$ The Works of James Buchanan, edited by John Bassett Moore, Philadelphia, Volume X., pages ro6, 34I.

72 The Works of James Buchanan, edited by John Bassett Moore, Philadelphia, Volume X., page 106. 
nomination for President. ${ }^{73}$ Curtis, who came from Massachusetts, a hot anti-slavery State, was a Whig and owed his appointment to the bench by President Fillmore to Daniel Webster, who had been one of the leaders of the anti-slavery forces. ${ }^{74}$

Time has proved that Justice Nelson, who belonged to the pro-slavery Democratic Party, but who came from the free State of New York, was the wisest of all the members of the Court in that he favored a decision which was a compromise. The eagerness of the majority of the Tribunal after Buchanan's election to the Presidency to hand down a decision in favor of the expansion of slavery within the Union, so far from settling the controversy in favor of the slave power, ultimately destroyed slavery where it existed under the protection of the Federal Constitution. For the judgment of the majority declaring the Missouri Compromise unconstitutional insured the Civil War.

Analyzing the reasoning in the opinions given by the majority of the Court in the Dred Scott case, Professor Corwin of Princeton University

${ }^{73}$ James Ford Rhodes: History of the United States from the Compromise of 1850, New York, 1896, Volume II., pages 179, 182, 184.

74 James Ford Rhodes: History of the United States from the Compromise of 1850 , New York, 1896 , Volume II., page 251 . 
pertinently says: ${ }^{75}$ "When, as in this case, the student finds six judges arriving at precisely the same result by three distinct processes of reasoning, he is naturally disposed to surmise that the result may possibly have induced the processes rather than that the processes compelled the result, though of course such surmise is not necessarily sound; but when he discovers further that the processes themselves were most deficient in that regard for history and precedent in which judicial reasoning is supposed to abound, his surmise becomes suspicion; and finally when he finds that beyond reasoning defectively upon the matter before them, the same judges deliberately gloss over material distinctions (as for example, in this case, the distinction between sojourn and domicile) and ignore precedents that they have themselves created (as for example, in this case, the decisions regarding the operation of State decisions upon questions of comity) his suspicion becomes conviction. The Dred Scott decision cannot be, with accuracy, written down as usurpation, but it can and must be written down as a gross abuse of trust by the body which rendered it."

${ }^{75}$ Edward S. Corwin: The Doctrine of Judicial Review, Princeton, r9r4, page ${ }_{56}$. 
In reading the above criticism it should not be forgotten that the two dissenting justices also allowed political considerations to influence their opinions.

With all their learning and sense of honor, the members of the Court were human. And even though they were protected by a life tenure in the positions that they held, and, so far as human ingenuity could provide, raised above and outside of political parties and interest, still they were men swayed by human passions. In a question which went, in the consequences that would flow from its solution, to the very vitals of the economic life of one of the two hostile sections into which the American people, as a result of slavery, had become divided, it was impossible for the nine members of the Supreme Court of the United States to divest their individual views entirely of their political and geographical sympathies. And whichever way they gave their individual judgments, they were sure to be attacked by one political party or the other as having violated their duty and been influenced by political considerations.

So it was that all these judges, who were able and capable men, with a high sense of honor, were necessarily swayed more or less by their political training 
and sympathies in reaching the conclusions which they did in the Dred Scott case. Their views were hotly criticised by the political party which held views opposed to their individual judgments. And the majority were accused by the Republicans of having exceeded their powers in the judgment at which they had arrived.

Of late years, too, in the United States, not only the State Courts and the lower Federal Tribunals have been attacked vigorously, by certain sections of the community because of the decisions that the judges of those tribunals gave (until the judges have been in a measure terrorized by public opinion); but even the Supreme Federal Tribunal of the Nation has been adversely criticised on account of its decisions. So far has this movement of attack of judicial decisions by the public gone in America, that the recall of judicial decisions and even the recall of judges have been advocated openly by men of high position and distinction as well as by others who knew little or nothing about what they have so glibly attacked and adversely criticised. In other words, the splendidly devised American Federal judicial system has not been able to satisfy all public opinion.

During the trial of the Dreyfus case in France 
before the Cour de Cassation-the highest civil tribunal of France, whose members were judges assuredly learned in the law both by years of study and practice on the bench-that high Court was attacked as being partisan and non-judicial in its decision in that celebrated case, just as years before the Supreme Court of the United States was accused of gross partisanship in its decision in the equally celebrated Dred Scott case. Those two Courts, though judicial tribunals, whose members were trained judges, with life appointments, did not satisfy all public opinion any more than the ad hoc Hague International Courts have satisfied all people.

Such a Supreme Court of the World, however, as the American delegation at the Second Hague Peace Conference was instructed to urge upon the Nations, would not be truly a Supreme Court of the World, in the sense that the Supreme Court of the United States of America or the Cour de Cassation of France are Courts. For back of such a Supreme Court of the World there would not be, any more than there was back of the International Tribunals which sat respectively upon the Alabama Claims and the Bering Sea Fur Seal cases, the power of compulsion. Just as in those two specific cases, as likewise in the Venezuela and other cases referred 
to an International Court named ad hoc, the execution of the judgment in every case taken to such a Supreme Court of the World would rest upon the willingness of the contending Nations to bow before and carry into execution the decree of the Court.

It is necessary not to forget, besides, that were such a Supreme Court of the Nations in existence, between it and the Municipal Courts of the individual Nations, there would exist, just as between International Tribunals named ad hoc and the Municipal Courts of the individual Nations, there does exist, an additional radical difference which has not been often observed. In the cases arising between individuals that are taken to the bar of Municipal Tribunals, the judges do not have to contend with their personal feelings in favor of one side or the other. Practically in all cases the judges do not know the litigants and the feelings of the judges are not enlisted strongly for one party or the other. If a case arose where the feelings of a judge were deeply stirred for any cause in favor of one side or the other, it would be improper for him to sit to try that case.

On the contrary, when Nations appear before an International Tribunal whether named ad hoc or sitting permanently, the litigants are not unknown 
to the individual judges. In cases between Nations, the way a question at issue is decided in favor of one side or the other may materially affect not only the interests of the litigant Nations, but also, favorably or adversely, the future status of other Nations that do not appear in the case at all. And as a consequence in political cases, the feelings of the individual judges of an International Tribunal, whether it be merely temporary or continuous in its status, will be more or less influenced by the interests of their own country, according as its interests directly or indirectly are more or less affected by the judgment to be rendered by the Court.

In those cases where the American Federal Supreme Court is called upon to judge between two individual member States of the Union, the conditions are more similar to the cases where individual citizens are the contestants before it than in the international cases when Nations appear as litigants before an International Tribunal. Why? Because when two States of the Union appear at its bar as litigants upon a question which is purely a bone of contention between them, not only is the power of all the United States, owing in part to the pressure of the outside world, behind the Court to enforce its judgment, but also the future safety and existence 
of neither State is really endangered by the decision. The individual States of the Union are not exposed to be divided up and annexed in parcels or in toto to some of the other States as is the case with members of the family of Nations. For between two member States of the United States the question of which is the stronger independently of the legal merits of any controversy cannot arise.

This immunity from dismemberment and absorption of one member State by another within the United States of America is due in part to the need of all the forty-eight States which constitute the Union to remain united and live in peace together in order to afford a united and strong front for mutual protection against the other Nations of the world. The elimination of the danger of absorption of one member State of the Union by another in contradistinction with the desire of members of the family of Nations to conquer and absorb another Nation, is due in part also to the fact that within all the bounds of the United States of America there is entire freedom of trade and migration, while between the members of the family of Nations there is restriction of trade and some restriction of migration. Consequently, the individual State prejudices of each member of the American Federal 
Supreme Court are not as strongly aroused, except in instances like the Dred Scott case, as are the national prejudices of the judges of International Courts in all cases which affect the relative power and influence of Nations.

In those cases between sovereign Nations, upon whose solution depends the future power of one or more of the litigant Nations, and possibly of other Nations not directly parties to the controversy, there is no more reason to expect the elimination of the nationalistic feeling of the individual judges, whether nationals of the contestants or not, than it was possible for the individual members of the Supreme Court of the United States of America to eliminate their political feelings in the Dred Scott case, in which was involved the fundamental political question of whether the free or the slave States of the North American Union should ultimately win the ascendency in the country. And consequently, in sitting upon such cases, every judge of a Supreme Court of the World would in some degree be influenced, in the present organization of the family of Nations, by the interests of his own country.

Commenting on international questions which might arise involving matters concerning a Nation itself as an integral entity, the Marquis of Salisbury, 
Prime Minister of Great Britain, in a dispatch addressed in March, I896, to Sir Julian Pauncefote, the British Ambassador, in Washington, said with pungent force: $:^{76}$

"If the matter in controversy is important, so that defeat is a serious blow to the credit or the power of the litigant who is worsted, that interest becomes a more or less keen partisanship. According to their sympathies, men wish for the victory of one side or another.

"Such conflicting sympathies interfere most formidably with the choice of an impartial arbitrator. It would be too invidious to specify the various forms of bias by which, in any important controversy between two great powers, the other members of the commonwealth of Nations are visibly affected. In the existing condition of international sentiment, each great power could point to Nations whose admission to any jury by whom its interests were to be tried, it would be bound to challenge; and in a litigation between two great powers the rival challenges would pretty well exhaust the catalogue of the Nations from whom competent and suitable arbiters could be drawn."

${ }^{76}$ John Bassett Moore: International Arbitrations to which the United States has been a party, Washington, r898, Volume I., page 964. 
Men who will at all times rise above their personal feelings and always try to find in their conscience the right thing to do, and then do it regardless of consequences to themselves, are rare, extremely rare. It is only such men, however-and how few and far between such men are, history tells us only too well-that could be depended upon at all times, whether sitting in an International Tribunal named ad hoc or a Supreme Court of the Nations, to avoid, in judging between the Nations, all elements of an opportunistic compromise and to strive honestly to give only a judicial judgment. A man of that type means the embodiment of the highest kind of courage. But would even a man of that high and noble stamp of character, deliberately decide in favor of what he believed would eventually destroy or seriously weaken and impair the power of his own country at the council board of the Nations? The individual judgments in the Dred Scott case seem to answer "no."

Supposing, however, that all the members of the family of Nations agree in setting up such a Supreme Court of the World, it should not be forgotten that there will be no force outside of the family of Nations compelling them to bow to the judgments of such a Tribunal. In that essential respect a 
Supreme Court of the World would differ radically from the Supreme Court of the United States of America. For at all times since the North American English-speaking colonies declared their independence, the member States of the United States of America, whether in the time of the Confederation or in that of the Union have had the consciousness of the existence of the powers of the rest of the outside world to induce the member States of the United States of America to bow in the beginning before the judgment of the Trenton InterState Court and afterwards before the judgments of the Federal Supreme Court. And yet when the States of that Union were divided into two camps of almost equal power that differed radically over an economic question which went to the core of the well-being of the Nation, the existence of that great outside force represented by the other Nations of the world, could not induce the member States of the North American Union to refrain from taking up arms. Regardless of the judicial judgment of the Federal Supreme Court about the slavery question, the two groups of States went to war. And it took four years of bloody and costly civil strife to decide which was the stronger.

After the judgment of the Court had been 
reversed by civil war, and slavery abolished in all the Union, the individual member States of the Union have once more bowed again and again to the judgments of the Federal Supreme Court. But if the Supreme Court of the United States could not by a judgment avoid a civil war within the North American Union over a political question upon which the member States were divided into two fairly equal groups, is it likely that a Supreme Court of the World will by its judgments be able to compass in peace the political quarrels dividing the powers of the world into two fairly equal groups? For in the latter case there will not be any force outside of the Nations of the world to restrain them from going to war as was the case in I86I for the member States of the North American Union, who nevertheless, in spite of the fact that there were many great and powerful Nations outside of the United States jealous of the power and success of the Union, resorted to war to settle a fundamentally important economic question of difference upon the opposing sides of which the member States of the Union had aligned themselves in two almost equally powerful groups.

Or to take an actual instance from the present politics of the world. To-day the Great War which is raging in Europe, raises the question:-If a 
Supreme Court of the World always in being, composed of fifteen judges appointed for life, had been sitting at The Hague in June and July, I9I4, would the existence of such a Tribunal have prevented the war any more than did the existence of the actual machinery for calling into being an International Court at The Hague for a single case? The Nations of Europe failed in this instance, even after President Wilson had offered his good offices by way of mediation, to avail themselves of the present facilities for submitting disputes between Nations to the judgment of an international judicial Court, appointed to sit at the Dutch Capital to judge the one single case for which each individual international Tribunal is under the present Hague conventions called into existence. If a small permanent Court-composed for example of fifteen judges-had been constantly in being at The Hague to judge all manner of cases of dispute arising between Nations, would the Nations of Europe have called upon the permanent Tribunal to settle the causes leading to the present war?

In view of the deep antagonisms existing between the Teutons and the Slavs in the east of Europe, between the Teutons and the French in the west of Europe, between Germany and Great Britain through the jealousy for commercial supremacy aroused by 
the keen competition for over-sea commerce and other deep lying causes stretching far back in the historic development of Europe, it is hard to believe that a Supreme Court of the World could have composed the quarrel of the European Nations in I9I4 any better than the actual present international judicial machinery provided for by the Second Hague Peace Conference could have done it, had the Nations appealed to one of The Hague International Courts named ad hoc. For no more than one of The Hague ad hoc Tribunals could a Supreme Court of the Nations have decided which group of Nations was the stronger, and so entitled to appropriate for itself the lion's share of the commerce of the world. That decision is now being sought in trial by battle.

It would seem then, that, in the final analysis, the only way a Supreme Court of the World could force individual Nations to bow before its decisions in all cases, would be the development of an international executive with sufficient power at its command to enforce the decisions of that Supreme Court of the World, just as behind the Supreme Court of the United States of America has stood, always excepting in the Dred Scott case, the overwhelming power of the Nation as against any one single member State of the North American Union. 


\section{PART VIII.}

Is there any force, however, to urge the family of Nations to form and enter into a world wide organization established for the purpose of eliminating war as the ultimate manner of settling their serious disagreements, and to replace war by the application of the rules of the Law between Nations as interpreted by a Supreme Court of the World seeking to award justice? Evidently there is no force or power outside of the family of Nations to compel them to form such a world confederation with the aim of preventing any member Nation from breaking out into war.

If there is no force outside all the Nations of the world compelling them to hold the peace among themselves comparable with the force representing the Nations of the world outside of the North American Union, which compelled the individual States of that Union to gradually unite into the single Nation of to-day and finally to bow before the decisions of the Supreme Court of the United States, it should not be forgotten that there is, however, within the Nations of the world themselves, a force driving toward peace. This force arises from the 
fact that the destruction of life and wealth wrought by modern war as well as the destruction of wealth caused by the preparation in times of peace for war is so tremendous that immense suffering both immediate and for the future are thereby inflicted upon the inhabitants of the belligerent Nations, and indirectly in many cases upon the neutrals. As with the opening of the present century the people have come to realize better the sufferings imposed by war, they' have dreaded more and more the outbreak of war, and have become by degrees less belligerent in their passions. In addition, owing to the interlocking more and more of the commerce of each Nation directly or indirectly with that of other Nations the world over, the bill for the wealth destroyed now by war must eventually be paid in a more or less degree by every Nation, even by the neutrals. For if the belligerent States become impoverished and bankrupt by war, they are in no condition afterwards to trade with those that remain neutral to the same extent that they did before the beginning of hostilities. And, though a Nation may remain at peace and neutral during a war, still, if its best customers are impoverished by war the neutral Nations must suffer in the long run owing to the inability of its former good customers to continue 
trading with the Neutral powers on the same scale as before the war. The gradual realization that the struggle for life is made more difficult for the surviving mass of humanity as a result of the destruction of wealth by war will strengthen the desire of mankind to eliminate war, as far as possible, by a reference, whenever it is possible, of international differences to judicial settlements instead of an appeal to arms.

One important factor helping the desire for the elimination of war, is the increasing realization of the people that war, among other effects, causes a serious impairment to the well being of the human race through the premature destruction of the young men of superior physical and mental attainments, for it is they who are naturally sent to the front while the weak and feeble in both mind and body. are more likely to be left at home. In that respect, war reverses for humanity the processes by which the human race seeks to improve the breed of horses, cattle and other domesticated animals. Thus, for instance, on every stock farm stallions, who are chosen with great care from among their fellows expressly because they are possessed of superior physical qualities over the average run of stallions, are kept solely for the object of serving the 
brood mares for the purposes of breeding. Not only are these stallions chosen because of their fine physical attributes to serve the brood mares, but also the greatest care is taken in choosing the mares which are best fitted to be given to each individual stallion for the purpose of the reproduction of their species. In that way the race of the noble horse, who has labored so long and well for mankind, has been kept up and improved. In the case of humanity, however, the men best suited physically and mentally to marry and father the next generation are, naturally, in war times, the first to be sent to the front, while the weaklings are the last to go. Consequently, a greater proportion of the children of the next generation are fathered by men of less desirable physical and mental types than usual, and some of the impairment of power of these weaklings is transmitted to their children, no matter how superior physically and mentally may be the woman with whom they each individually mate.

The desire to avoid war, because of the fear of the loss of life and the destruction of property and the waste of labor that result from war, is not a sufficiently strong force to cause Nations in all cases of difference to resort to international judicial proceedings rather than to war to settle their 
disputes. The desire to possess what others already have in many instances is so strong as to lead to a trial by battle to find out which side is the stronger. The experience to be found in the history of humanity would seem to show that if all war between Nations is to be avoided, then some international or supernational force must be devised which will compel Nations to take their differences into International Courts, or the International Supreme Court of the possible future, just as within Nations a force has been devised which compels individuals to take their disputes into Municipal Courts. If it was not for the power of the sheriff, with all the power of the State looming up behind him, how many individuals would refuse to appear before Municipal Courts who now quietly obey the summons to appear before the Municipal Tribunals. And in questions which affect the vital interests of Nations, it may be expected that the Nations will not go into Court to settle such questions unless there is a force sufficiently strong to compel them.

In what way is the upbuilding of some general international organization of sufficient force and power to compel all members of the family of Nations to desist from war and submit all their differences, both legal and political, to one of the 
International Courts named ad hoc at The Hague, or to a Supreme Court of the World most likely to be expected or attained?

To successfully establish at The Hague a Supreme Court of the Nations of the world, modeled upon the Supreme Court of the United States of America, to settle the differences of the Nations, involves a problem different in many respects from that which confronted the thirteen American States when they originated and set up their present Federal Supreme Tribunal. In the original thirteen American States, with a local exception in part of Pennsylvania, the people of all the States spoke, with slight variations, the same English language; and a common tongue is perhaps the most important basis of nationality. And these thirteen States were drawn closer to one another and impelled to join together because of their fear of the outside world. The Nations of the world, unlike the original thirteen North American States, do not speak one language, but on the contrary, speak even more tongues than there are separate and individual Powers in the world. And the Nations of the world are not driven by fear of a power or force outside of their circle into a common union whose individual members 
shall submit their differences to a Supreme Court of the World, in the same way that the member States of the Confederation of the United States of America were compelled, by the fear of the outside world, to join together more closely and agree to submit their discords or quarrels to the Supreme Court of the United States.

The teaching of the past efforts of humanity to minimize or eliminate war from the politics of the world show that this cannot be accomplished in the international sphere of the family of Nations by one master stroke of statecraft, but that that aim can only be attained, if it is attainable, by the slow and gradual processes of evolution. ${ }^{77}$ All attempts up to now to devise some scheme or plan to altogether eliminate the scourge of war from human affairs have failed, just as all efforts so far to stamp out consumption and cancer have failed. But on many single occasions, war has been avoided by substituting for war an appeal to judicial proceedings. In such cases, however, no attempt was made to eliminate all war

${ }^{77}$ Thomas Willing Balch: L'Évolution de l'Arbitrage International Revue de Droit International et de Législation Comparée, Brussels, I908, also reprinted in book form at Philadelphia, 1908.-John Bassett Moore: The Peace Problem: Columbia University Quarterly, June, I916. 
for all time from human affairs. Consequently, obedient to the natural law of evolution, in our efforts to replace international war as much as possible by international justice as the final judge between Nations, we should seek to advance the cause of international justice step by step rather than hastily and prematurely to establish a world confederation with a Supreme Court of the World. Such a Supreme Tribunal of the Nations would at present lack behind it that overwhelming power to enforce its decisions which is found personified back of the judgments of Municipal Tribunals in all the power and force of that particular Nation of which each individual Municipal Court forms a part.

As a consequence such a Tribunal, just as the International Tribunals now instituted ad hoc under The Hague agreements, practically could only deal with legal cases, that is those cases which, because no vital interests of Nations were at stake, the Nations would be willing of their own accord to bring to its bar.

It may be perhaps that through the assembling at recurring intervals of Peace Congresses at The Hague, such as those of 1899 and 1907, something like a Parliament of the Nations will be developed gradually in time; that the present pro- 
visions for the erection of International Tribunals ad hoc will be successfully elaborated into a Supreme Court of the World, just as the Inter-State Courts provided for in the ninth article of the Articles of Confederation of the United States of America were subsequently developed into the Supreme Court of the United States; and also that an international executive with some power at its disposal to enforce its will, will eventually, by degrees, be born. In that way, if so much is once successfully accomplished, the family of Nations would be on the high road to a loosely formed world confederation.

That would reverse the process in which the period of civilization immediately preceding our own period of civilization reached in its old age-through the conquest of the then known world by the Roman Empire, and the consequent extension of the Pax Romana wherever the power of Roman arms extended-a semblance of world peace.

It should not be forgotten, however, that after the great summer of the Roman civilization had closed, there succeeded a long winter of more than four centuries, before our own summer of civilization began. As a number of successive civilizations have been born and died in the past, it is altogether likely that our Heavenly Father in his own good 
time-when our own period of civilization has been sufficiently benumbed by the socialistic status which seems to be growing up within our own civilization, as socialism though not known by that name grew towards the close of the Roman period-will provide once more, as so many times before, the Barbarians to end the present summer of civilization and begin the next great winter that must precede the birth of the next period of civilization. ${ }^{78}$ It is well in dealing with such problems to remember the wise words of the Emperor Marcus Aurelius, a propos of his signet ring: "This, too, will pass away."

So in striving to maintain peace among the Nations by the application of international justice to settle the quarrels of the Nations instead of by bloody and destructive war, let us remain practical in our aims instead of being led by visions and dreams to possible disappointment.

${ }^{78}$ W. M. Flinders Petrie: The Revolutions of Civilization, 1911. 


\section{PART IX.}

Both the success and failure of the Supreme Court of the United States of America in preventing civil war within the United States would seem to warn that too much should not be expected in the matter of eliminating war between Nations by any sudden change in the present method of creating International Judicial Tribunals ad hoc into a permanent Supreme Court of the World composed of a small number of judges actually representing in their own persons only a small number of Nations. If such a Tribunal is really to help in keeping by. its decisions peace among the Nations when political disputes arise, something else besides the setting up of such a Court must be devised and developed by the family of Nations. To find that something will be no easy task.

In the affairs of Nations, as in other spheres of action on and in our planet, the forces of dynamics must never be lost sight of. While all sovereign Nations are theoretically and juridically equal, and count the one as much as another in deciding the development of International Law and the manner 
of its interpretation, ${ }^{79}$ nevertheless, some, owing to a variety of reasons, are actually stronger than others in shaping the politics of the world. And the relative strength of the Nations to one another, obeying a universal law of nature, are in a continuous state of flux. Some of the strong Powers of a half century ago have lost part of their pre-eminence, while others that were then comparatively unheard of, have not only gained in prestige, but because of their practically untouched virgin resources, give promise of rising still higher in the councils of the world. Also other Nations, which, in past centuries, were strong Powers and had fallen behind in the race of the Nations because they had exhausted their available resources and failed to adapt themselves to the change wrought in the world by the new discoveries of mankind, seem after lying fallow for a time to be rejuvenated by a new birth.

While history shows conclusively that the application of international justice as a means of settling

${ }^{79}$ Emerich de Vattel: Le droil des gens; ou, principes de la loi naturelle, Amsterdam, 1775, Preliminaires, Sec. 18: "Une petitere publique n'est pas moins un Etat souverain que le plus puissant royaume." Chief Justice Marshall in The Antelope, ro Wheaton, Uniled Stales Supreme Court Reports, 1825, page 122 said: "No principle of general law is more universally acknowledged than the perfect equality of Nations. Russia and Geneva have equal rights." 
the quarrels of Nations has proved itself often a successful and precious instrument to avoid war, nevertheless, ever since the judicial settlement of the Alabama Claims in 1872 by the Geneva Tribunal, it has become more and more clear with every case of difficulty between Nations that has been decided since that time either by an International Court on the one hand, or by war on the other hand, that the disagreements which arise between Nations naturally divide themselves into two great categories.

In the history of the Supreme Court of the United States this same dual division of the controversies that might arise between the member States of the United States was observed at least as early as 1838 . In the case of Rhode Island and Providence Plantation vs. Massachusetts, Justice Baldwin commentating on the differences that could arise between the member States of the Union, said they might either be on the one hand of a civil or judicial nature, and on the other hand, of a political character. In a dissenting opinion in the same case, Chief Justice Taney spoke of judicial and political cases, and defined the difference between the two groups of cases to which he applied those terms. To designate the two great divisions into which the disputes arising between Nations seem naturally to divide, 
the French publicists applied to them respectively the terms cas juridiques and cas politiques. Among English speaking international jurisconsults, Westlake seems to have been the first to name these same two great classes of cases into which international difficulties naturally divide, respectively on the one hand legal or juridical cases, and on the other hand political cases. Commenting on this aspect of international relations, Westlake, a profound and clear thinker, has pointed out that, as is proved by the submission of the Alabama Claims case to the Geneva Tribunal, a great deal may be hoped for from the submission of differences between Nations to International Courts of Justice. Then he continues: 80 "I am hopeless of good results from general treaties for arbitration, never having seen, or been able to devise, any formula that can distinguish with sufficient precision the cases in which it is an applicable remedy from those in which it could not be submitted to. We may say that it is suitable for cases of a legal character, not for those of a political one. And that distinction is probably intelligible enough for practical purposes, though not precise enough for a treaty."

80 Thomas Balch: International Courts of Arbitration, 1874, 6th edition, Philadelphia, 1915, page 63 . 
Professor Oppenheim, Westlake's successor in the Whewell chair of International Law in Cambridge University, likewise has recognized this two-fold division into which the cases of disputes between Nations naturally are divided. At the same time he has pointed out that it is often difficult to say where one set of cases ends and the other begins. ${ }^{81}$ Among American publicists, Hershey likewise has recognized this two-fold division. ${ }^{82}$ Elsewhere the present writer has maintained that the fundamental differentiation between legal or juridical cases on the one hand and political cases on the other hand was, that in the former class of cases the independence or future political development of Nations were not involved, while in the latter class they were menaced. ${ }^{83}$

${ }^{81}$ Lassa Oppenheim: International Law, 2nd edition, London, rgr 2, Volume II., pages 3-4.

${ }^{82}$ Amos S. Hershey: The Essentials of International Public Law, New York, r9r 2, page $32 \mathrm{r}$.

83 Thomas Willing Balch: Différends juridiques et politiques dans les rapports des nations; Revue Générale de Droit International Public, Paris, r9r4, page 18r.-Legal and Political International Questions and the recurrence of War; a paper read before the American Philosophical Society held at Philadelphia for the Advancement of Useful Knowledge, April 15th, 19r6; Philadelphia, r917, page 5; reprinted from the Proceedings of the American Philosophical Society. 
Humanity in its eager desire to avoid the misery entailed by war, hailed with delight the principle of mediation as sanctioned by the Congress of Paris in 1856 , only to realize in a few years that mediation would not do away with all wars. Then the successful avoidance of a possibility of war between the United States and Great Britain by the judicial settlement by the Geneva Tribunal in I 87 I-72 of the Alabama Claims, encouraged many individuals to believe that by a recourse to similar International Courts named ad hoc war could be avoided more often in the future than it had been in the past. And the success attending the International Courts that judged in the Bering Sea Fur Seal case and other international disputes increased the hope that judicial settlements would more and more do away with war. Then the peoples of the world acclaimed with enthusiasm the call of the Emperor Nicholas the Second in 1898 to a Conference of the Nations for the purpose of reducing armaments, a result which unfortunately was not accomplished. But the Conference in 1899 and its successor in 1907 made provisions making it more easy to call into existence International Tribunals appointed ad hoc to decide between the Nations. These provisions filled the world with hope and 
expectancy. For up to that time, most of the pacifists, unlike the jurists, had not realized what the Geneva Tribunal of $187 \mathrm{I}-72$ and its successor, the Paris Tribunal of $\mathbf{I} 893$, had actually accomplished in solving two troublesome international disputes by judicial settlements. To many of these people, the suggestions presented at the two Hague Conferences came as someting almost new. For they had not understood that already, in several cases, International Judicial Tribunals had judged between the Nations.

Once more, however, the Nations have been disillusionized by the present Great War as to the possibility of avoiding all war by referring international disputes to International Courts named ad hoc for judicial settlement. And partly as a result of this new light which has at last dawned on the world, much has been said and heard since the present titanic struggle began, about the creation of a Supreme Court of the Nations with the intent of securing to humanity world peace.

In trying to build a permanent International Tribunal after the manner of the Supreme Court of the United States that shall judge successfully in all cases between the Nations, we must not think that it can be erected with its necessary adjuncts by 
one Conference of the Nations, or even by one generation of humanity. The establishment of such a Court is an ideal that the human race may well strive at all times to reach. In actual fact great progress towards the realization of such a Court has been already accomplished.

Indeed, the task before the Nations in setting up such a Court is not unlike that presenting itself to the mountaineer who wishes to climb a high but apparently inaccessible mountain top. He attempts to scale the peak from all possible and impossible sides. From each unsuccessful attempt he learns something about the problem confronting him. He may spend years before he realizes his object, and even in many cases he has only prepared the way for a climber of a younger generation to succeed because of the discoveries made upon the mountain itself by the climber of the older generation. Edward Whymper attacked the Matterhorn or Mont Cervin for five years before he and Michel $\mathrm{Croz}$ found the way to the summit. Other, higher and more difficult peaks, for instance Gaurisankar and Kinchinjunga, still baffle all attempts to reach their summits and seemingly give no promise that man will on his own feet ever attain their snow clad summits. 
The practical development of mountaineering, since Doctor Paccard of Chamonix found the way to the summit of Mont Blanc in $1787,{ }^{84}$ has developed a set of primary rules which every first rate climber knows must be observed if he wishes to succeed.

The first and most important of these rules is to go slowly. As the mountain climbers of Italy so truly say:

\section{Chi va piano, va sano, \\ Chi va sano, va lontano;}

a truth embodied also in the well known maxim of the French mountaineers:

Plus doucement on monte, Plus vite on arrive au sommet.

Or as an Italian guide once expressed it to the writer:

Chi va forte, va a la morte.

An apt instance of the fact that political and social developments can be accomplished only gradually is shown by the slow but steady formation of that political and social organism which to-day is the virile French Nation. One of the early Kings of Paris who wished to extend his territorial domains and was actually thinking of

${ }^{84}$ Douglas W. Freshfield: The Growth of a legend: Paccard v. Balmat; Alpine Journal, London, I913, Volume XXVII., page 202. 
capturing and annexing by force of arms the neighboring town of Saint Denis, a short distance to the north of Paris, took counsel with his leading men as to the advisability of risking such a step. One of his counsellors in commenting on the proposition, said: C'est le premier pas qui coute. With the addition of that little burg to the landed possessions of the feudal house that ruled in early Paris, began that territorial growth in the Ile de France, round Paris as the kernel, which resulted in the course of centuries in the creation of the French Nation.

At the end of the present Great War, the family of Nations, realizing the immense losses caused by the conflict, perhaps will feel inclined to attempt, in order to avoid another such cataclysm, to establish at once through a Third Hague Peace Conference some sort of nebulous world organization whose aim it will be to prevent the outbreak of war in the future. If such an attempt is made, the plan to have any success at all, must be based on the idea of doing justice to all, and not, as the famous Grand dessein of Henri Quatre, of placing one group of Nations in control rather than another, no matter with how clever a subterfuge the attempt to gain power or leadership for one Nation or group of Nations may be at first disguised. 
So long as questions may arise involving in their solution the independence and future political power of Nations, one of the best ways to work for the maintenance of peace among the Nations would seem to be, while perfecting so far as possible the constitution of the present International Tribunals named ad hoc, to seek to eliminate so far as possible the probable causes for war. Thus, for example, the United States of America could give in the Alaskan lisiere to the Dominion of Canada in exchange for a little land somewhere else, say the islands of Campobello and Grand Manan, two narrow strips of land of sufficient width to allow the building of two railroads from the hinterland across the lisiere to two of the fiords that bulge into the lisiere with sufficient land on each fiord to allow two ports to be established. In that way merchandise destined for the hinterland of the Alaskan lisiere could be discharged at those ports and shipped into or out of the Canadian territory without being subjected in any way to or delayed by the tariff duties of the United States. ${ }^{85}$ Then in order to send goods by way of the Pacific Ocean to the Yukon district of

85 Thomas Willing Balch: La Frontière Alasko-Canadienne, Revue de Droit International et de Législation Comparée, Brussels, I902, pages 5-23: The Alaska Frontier, Philadelphia, 1903. 
Canada, it would no longer be necessary, in order to avoid the payment of American' customs duties, to send the merchandise by way of Port Simpson. It could be sent via some port more to the north, like Skagway, for instance, and directly over the White Pass to the Yukon Valley.

Also the Law of Neutrality could be revised in the interest on the one hand of curtailing the area of war once it had broken out, and on the other hand of shortening so far as possible its duration. Thus if all the members of the family of Nations gave their adhesion to a more exact definition than now exists of the rights of neutrals as well as their duties vis-a-vis of belligerents, the danger of future wars extending the area of conflagrations beyond the limits of the original contestants would be lessened. A vexatious and difficult question touching the intercourse and well being of the members of the family of Nations is how to insure the freedom of the seas for peaceful commerce in times of war as well as in times of peace. Can any plan be devised by which all Nations at all times will feel secure in their oversea trade? If that could be successfully accomplished, a great stroke for the preservation of international peace would have been struck.

Above all, as was suggested many times and in 
many quarters before the Great War began, and as has been repeated recently by the Pope, Benedict the Fifteenth, a real effort should be made by the Nations to reduce their armaments upon the basis of a quid pro quo. That may be looked upon as a sine qua non of any real attempt to do away with war.

It is possible that the undoubtedly increasing growing desire during recent years for international peace among mankind, may cause Nations who are more or less contiguous and neighbors to one another, even though speaking different languages, to draw, owing to the fear of attack from other quarters of the world, closer together in some manner so as to avoid war among themselves and so the better be able to resist attack from some other section of the planet.

For instance, the Swiss Cantons, though speaking three different languages, French, German and Italian, were drawn gradually together for mutual defence, owing to the fear of aggression by the powerful States that had grown up all about them.

A test of the practicability of establishing a World Court would be for allied Nations, as Britain, France and Italy, for instance, being willing to establish a Supreme Court that should judge all questions, political as well as legal, without ex- 
ception, arising between themselves. If Nations that are allies in war are not willing to agree on such a Court for themselves, how can all the Nations of the world be expected to agree on a Court which shall judge without reserve all questions arising between them?

Perhaps the world in time may become divided into several distinct groups of Nations based upon geographical reasons. And the members of each group, because of the fear of attack of some other group also formed on geographical alignment, may seek to minimize and eliminate the chances and causes of war possibly arising between the Nations belonging to the same group. Once such a stage in human polity has been reached, perhaps it may be possible in the future, to arrange for some scheme of world wide organization that will tend gradually to reduce the recurrences of war to the minimum. 


\section{PART X.}

The great difficulty in enforcing peace throughout all the world, however, is that there is no force outside of the world to drive the peoples of the earth to remain united in order to avoid war among themselves. And this is true whether the peoples be organized as separate Nations as at present, or according to any other scheme that may be devised. If the peoples of the world are once united into a world confederation, or a single world State, in the absence of any outside force to make it their mutual interest to hold together for protection against outside aggression, the desire of the peoples in various parts of the earth to gain more than their fair share of the fruits of the earth will, judging by the past history of humanity, result in war. That is the weak point in all plans for maintaining world peace. All Nations, no matter with what grandiloquent and honeyed phrases their aims may be expressed, are essentially selfish in their foreign policy. Nations do not go to war to help another Nation out of regard for the latter. Nations go to war solely for their own interests. So it has been in the past, and so it will be in the future. Alliances 
between Nations are formed upon mutual interests. Thus early in the present century, Great Britain and France were driven through fear of the growing power of Germany into an alliance that was patent to all the world. And under the stress of the menace to their respective vast colonial empires resulting from the growing power of Germany and the desire of Germany for colonies, France and Great Britain, upon the basis of give and take, rounded off, so far as they could, the sharp corners that existed between them. Thus, for example, France recognized Great Britain's occupancy of Egypt, while Great Britain supported the claims of France to the possession of Morocco. And yet for centuries before that France and Great Britain had been constantly opposed to one another, and had fought many long and bloody wars. But the danger threatened by another power to the possessions of both produced the entente cordiale.

As one of the greatest of living international jurisconsults, Professor John Bassett Moore, has aptly said, the possibilities to use force to maintain peace among the Nations depends in part upon public opinion or sentiment. In a letter addressed to the present writer on February 9th, 1917, the distinguished professor of International Laws of 
Columbia University said:: " $\mathrm{I}$ am inclined to think that the possibilities of force in maintaining peace are often exaggerated by the omission of one fundamental consideration-namely, that the availability of force in the long run depends on opinion or sentiment. During the past century there have been almost innumerable civil wars, one of the greatest being that which for four years swept over the United States. And yet we had a national government, and under it an administration far more centralized than any one now proposes to establish over nations. But, when the sentiment of the country divided, its force likewise divided, and war naturally resulted. The fundamental problem therefore is how to preserve unity of sentiment. Let no man think that our country could not be divided again if one section should seek ruthlessly to impose its will upon the other in a matter regarded by the latter as politically or socially vital; and in such event, even though one side should again subdue the other, there would nevertheless have been war. Let us also remember that beyond a certain point the suppression of sentiment by force is tyranny."

${ }^{86}$ This extract is printed with the approval of Professor Moore. 
The illumination cast upon the evolution of international justice by the way in which the Supreme Court of the United States was evolved; the remarkable success on the one hand of that great Court in deciding between two individual member States of the United States; and the failure on the other hand of that same high Tribunal in attempting to decide between all the member States of the North American Union when they were divided into two fairly and evenly balanced groups with diametrically opposed interests over the slavery question-give warning that the peoples should not be fooled into believing that by the hasty creation, after the present Great War is ended, of a Supreme Court of the Nations all war will be ended. That would be to mislead the Nations with false hopes and expectations. For the existing international judicial machinery is not to-day the weak point among the forces and institutions forged by the human race to deliver itself from the curse of war. The crucial problem with which the world must wrestle in order to avoid war is more complex than the establishment of a Supreme Court of the Nations.

The real underlying problem that humanity faces in seeking to eliminate war is that there are two sets of primary questions constantly arising between 
two or more agglomerations of peoples. The one set of such questions, no matter how they may be decided in favor of one side or the other, do not seriously threaten the well-being or prosperity of either group of peoples who are interested in any particular question. Those are legal questions, for they may be settled by jural proceedings upon the basis of justice, since the life and future well-being in the world of neither group of people is really at stake, whichever way those questions may be decided. The second class of questions, however, differ radically from the first or legal group of differences. For upon the successful solution one way or the other of the questions belonging to the second class, there does depend the future wellbeing of one or more of the agglomerations or groups of people actually interested in the solution of such questions and the resulting power and ability of such groups to obtain the fruits of the earth. Such questions, which are political in their nature, can only be solved by force or power, which in the last analysis means a resort to war.

A practical way, though, to aid in the maintenance of peace in the world, would be for future Hague Peace Conferences to add to their efforts at legislation, the assumption of the function of con- 
ciliation. The First and the Second Hague Peace Conferences in their efforts to change the Law between Nations in the interest of peace and harmony in the world, assumed in a measure the function of a world legislative body. The Third and subsequent Conferences could take up also, from time to time, the task of trying to conciliate so far as possible the clashing interests of rival Nations. In that manner not only would a solution by an appeal to war of some vexatious questions be avoided, but also probably through such conciliation as well as the development of the Law between Nations by the legislative activities of future Peace Conferences at The Hague, some of the questions arising between Nations which to-day belong to the realm of political questions, could be transferred by degrees to the domain of legal questions.

For instance in the past the use that could and could not be made of neutral territory to aid belligerents fell within the domain of political questions. Since the time, however, when Jefferson interpreted Washington's neutrality proclamation of 1793 in a series of important state letters, the use that may and may not properly be made of neutral territory for the advantage of belligerents, has 
passed by degrees largely into the area of legal questions. For whereas before Washington's proclamation was issued, the status of what could and could not properly be done to aid belligerents, was in a state of flux, since then the rights and duties of neutrals in the premises have become in large measure defined by the general agreement of the members of the family of Nations.

In the development of future Hague Peace Conferences along the line of conciliating the claims of rival powers, there is hope that progress in lessening the chances and occurrences for the outbreak of war between two or more agglomerations of large masses of humanity could be made and so increase gradually the substitution of international justice for international war. In that way there would seem to be a promise of something substantial for the promotion and preservation of peace, and for warding off from humanity the horrors and misery that accompany war.

Instead of trying to end war for all time in the future by one stroke of magic by merely urging the erection of a Supreme Court of the World and a League of Nations to support it, the best friends of peace and the most resolute opponents of war are those who will teach and labor to curtail by slow 
degrees the occurrences producing war. They will make every effort to transfer gradually as many as possible of the problems arising between Nations which to-day are political questions into the realm of legal questions. For the whole history of humanity teaches that those who wish to make wars less frequent and peace more durable must be content to proceed slowly and to attain their aims step by step and not try to encompass them at one bound. And above all the study of the career of the United States Supreme Court teaches that there are possibly limits in securing world peace beyond which humanity may not hope to go. 


\section{EPILOGUE.}

When the present writer began shortly before the breaking out of the Great War to study the record of the Supreme Court of the United States, it was with the view of advancing an argument in favor of the early creation of a Supreme Court of the Nations as the best and easiest means of insuring peace between the members of the family of Nations. As the study advanced, however, the writer was forced gradually to realize that there were limitations to the possibilities of securing world peace by the mere establishment of such a Tribunal.

Nevertheless, the author believes that much can be done to make the recurrences of war less frequent. With that object in view he submits the present study in all humility to the jurists of the world with the hope that it may prove of some service in helping the efforts of humanity to render wars less frequent and peace more durable.

\section{THE AUTHOR.}

Philadelphia, November, I9I 7. 


\section{N DEX.}

Ableman, Stephen V., vs. Sherman M. Booth and the United

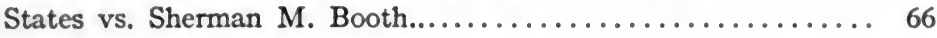

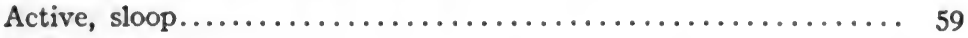

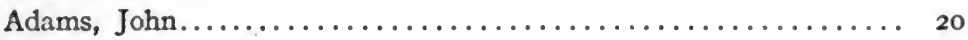

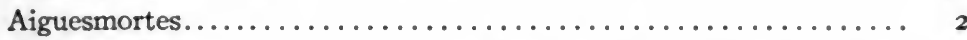

Alabama Claims......... 3, 4, 45, 86, 97, 98, 113, 136, 137, 139

Alabama, vs. Georgia......................... 46

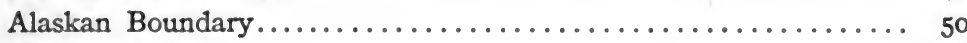

Alaskan lisière.................................. I44

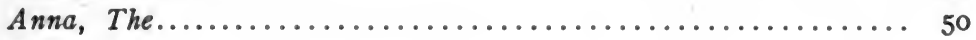

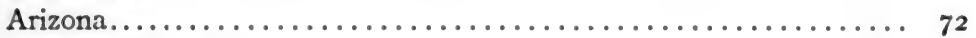

Arnold, Welcome.......................... 24, 26

Articles of Confederation.............. 7, 21, 22, 29, 30, 38

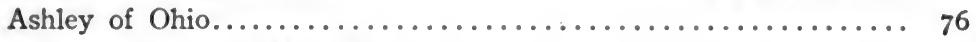

Aurelius, Emperor Marcus.................... 133

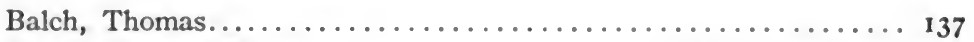

Balch, Thomas Willing.............. 85, 97, 130, 138, 144

Baldwin, Justice...................... 39, 42, 136

Baltimore, Lord........................... 11, 12

Belligerents.............................. 153, 154

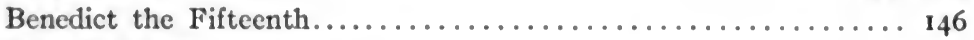

Berard, Victor............................... 85

Bering Sea Fur Seal Case............. 4, 86-87, 103, 11 3, 139

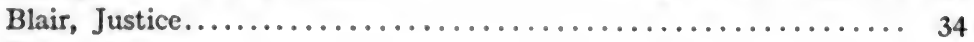

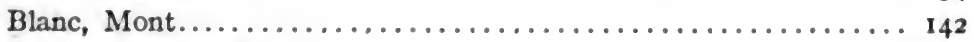

Booth, Sherman M...........................66-68

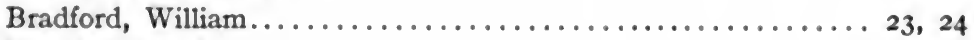

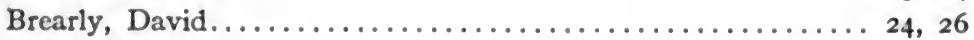

Britain, Great............... 2, 7, 21, 103, 104, 105, 139, 146

Britain, Great, and Germany......................... 122

Brown, Philip Marshall........................... 102

Buchanan, James................ 68, 76, 78, 107-109 
California

Campbell, Justice.

Campbell vs. Hall. I06

Campobello and Grand Manan Islands.

Canada... I44

Carson, Hampton L. I4I, 145

Casablanca Affair $59,61,62$

Cas juridiques. 87

Cas politzques. 137

Catron, Justice. 137

Cervin, Mont. 106

Charles the Second I 41

Chase, Samuel... II, I4, I6, 18

Chinese Empire. 20

Chisholm vs. Georgia.

$33,35,36$

Civil War, I86I-I 865 . $8 \mathrm{I}-83, \mathrm{I} 2 \mathrm{I}$

Clay, Henry. 72

Columbia University........................ 150

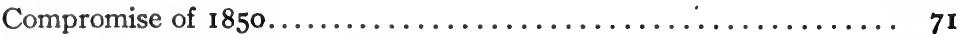

Compromises in the Constitution............... 68, 91

Connecticut. $7,8,10,13,15,16,18,19,21-28,85$

Continental Congress. $19,21,23,60,61$

Corwin, Edward S. 109,110

Coucy-le-Château. 105,113

Cour de Cassation of France.

Cromwell, Oliver 141

Croz, Michel

Curtis, Justice Benjamin Robbins. $77,78,108,109$

Cushing, Justice

Daniel, Justice........................... 106

Delaware.............................. 13

Dickinson, John............................ 27, 32

Dred Scott case..... 68, 73-80, 83, 101, 106-109, I1 2, I13, 117, 119, 123 
Dreyfus case

Egle, William $\mathrm{H}$. $11,16,17,25$

Eleventh Amendment to the Federal Constitution 35,52

Entente cordiale. 149

Epilogue 156

Federal Constitution 35-37

Federal Convention. $13,30,32$

Fillmore, President. 109

Five Nations, the

Ford, Worthington C........................... 78

France.................... 12, 85, 95, 142, 143, 146, 149

Freedom of the seas......................... 145

Fremont, John C...................... 78

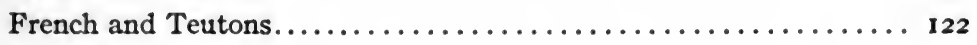

Freshfield, Douglas W......................... 142

Fuller, Chief Justice...................... 49, 50

Gaurisankar............................ r $\mathbf{4} \mathbf{r}$

Geneva Tribunal.......3,4, 45, 86, 87, 98, 103, 136, 137, 139, 140

Georgia................................... 33-35

Georgia vs. Tennessee Copper Company............... 55

Germany............................ 2, 149

Germany and Great Britain....................... 122

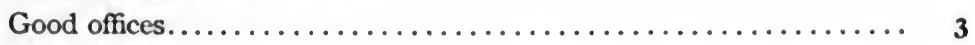

Grand dessein.................................. 143

Great War, the.............. 102, 121, 140, 143, 146, 151, 156

Greek City-States........................ 85

Green, Nathaniel............................... 24

Grier, Justice.......................... 106, 108

Griffin, Cyrus...................... 24, 26, 27

Hague Courts, the.............. 6, 87, 102-105, 113, 122, 131

Hague Peace Conference, First, 1899..... 3, 4, 87, 88, 131, 139, 153 
INDEX.

PAGE

Hague Peace Conference, Second, 1907... 4, 87, 88, 99, 100, 113,123 ,

129, 131, I39, I 53

Hague Peace Conference, Third..................... 143

Hague Peace Conferences and Conciliation............ 153, 154

Hamburg, Free City of ...................... 85

Hardwicke, Lord Chancellor..................... I3

Hazard, Ebenezer......................... 10, 16

Hazard................................. 4I

Henri Quatre............................... 43

Hershey, Amos S........................ 97, 138

Higgins, A. Pearce.......................... 4

Hoadly, Charles J......................... 10 6

Hollingsworth et al. vs. Virginia................... 35

Hopkins, Stephen............................ 21

Houston, William Churchill..................... 24, 26

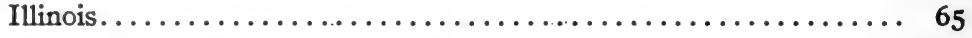

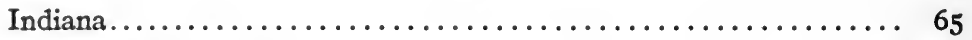

Indiana $v s$. Kentucky........................... 47

Instructions to American delegation at the Second Hague Peace

Conference concerning a proposed World Court.......... 99-ior

International Courts of Justice...: 4, 86, 87, 97, 99, 102, 114, I15, I19, 128, 132, 134, 137, 139, 144

International Law, Private.................... 56

International Law, Public................ 56, 124, 134, 153

Inter-State Tribunals in American Colonies............. 89, 132

Jackson, Andrew............................ 65

Jay, Chief Justice........................ 34, 36, 86

Jefferson, Thomas......................... 20, 153

Johnson, Dr. William Samuel.................... 16

Johnson, William Samuel...................... 23, 25

Jones, Joseph............................. 24

Judicial settlements, international.................. 84-86 
Kansas vs. Colorado............................ 53

Keith, Charles Penrose......................... I I

Kelby, George............................ 8

Kinchinjunga........................... 141

King in Council.................... 10, 11-13, 17-19, 22

Kings of Paris......................... 142

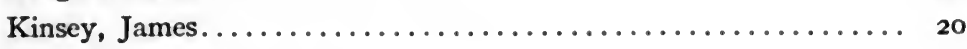

Lake dwellers of Switzerland................... I

League of Nations........................ 154

Legal Questions.................... 97, 136-138, 152, 155

Limes Imperii Romanii...................... I

Linn, John B......................... I I

Louisiana vs. Mississippi...................... 49

Louisiana purchase...................... 70, 72, 74

Louisiana vs. Texas............................. 55-56

Mansfield, Lord.......................... 11, 13

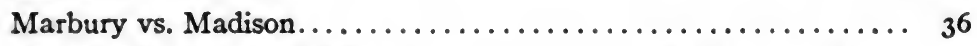

Marshall, John, Chief Justice............ 36, 38, 40, 63, 94, I35

Maryland.......................... 11, 13

Maryland vs. West Virginia................... 5 I

Massachusetts........................... 13, 41-43

Massachusetts vs. New York.................... 29

Matterhorn........................ 141

McLean, Justice....................... 44, 77, 78, 108

McMaster, John Bach..................... 72, 75

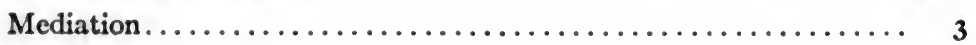

Mexico...............................

Middle Ages.......................... 85

Missouri....................... 7 r, 72

Missouri Compromise............... 71, 77, 79-81, 106-109

Missouri vs. Illinois............................ 54

Missouri vs. Iowa....................... 46

Missouri vs. Kansas....................... 50 
Missouri vs. Kentucky ........................ 47

Missouri vs. Nebraska.......................... 48

Montesquieu............................... $3 \mathbf{I}$

Moore, John Bassett............ 76, 78, I07-108, I I 8, I30, I 49

Municipal Courts............................. 6

Municipal Tribunals................... I 14, 128, I31

Napoleon............................... 70

Nelson, Justice Samuel. . . . . . . . . . . . . . . . . . . 108-109

Nelson, Thomas............................ 2 I

Netherland, New......................... 7-9, 85

Netherland, United........................... 2, 9

Neutrality............................ 145, I53-154

New Hampshire vs. Louisiana....................... 5I

New Haven... . . . . . ......................... 7 79, 85

New Jersey... . . . . . . . . . . . . . . . . . . . . . I5, 18-19, 39-40

New Jersey vs. New York....................... 39-40, 6r

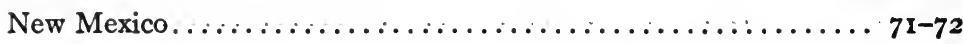

New York. ................... 9, 14-15, 18-19, 28, 33, 39-40

New York vs. Connecticut. ........................ 39

Nicholas the Second. . . . . . . . . . . . . . . . . . . . . . 3, I39

Ninth article of the Articles of Confederation.......... 27, 88-90

North Atlantic Fisheries Case.................. 87, 103-104

Ohio, State of, against.Territory of Michigan............ 64, 65

Olmstead, Gideon........................... 59, 64

Oppenheim, Lassa......................... 97, 138

Order in Council............................. 13

Osborn, Henry................................. 23

Paccard, Doctor............................ 142

Paris, Congress of, $1856 \ldots \ldots \ldots \ldots \ldots \ldots \ldots \ldots \ldots \ldots$

Paris Tribunal, $\mathbf{1} 893 \ldots \ldots \ldots \ldots \ldots \ldots \ldots \ldots \ldots \ldots \ldots$

Parliament of Nations........................ I I

Pauncefote, Sir Julian....................... I 8 
PAGE
Penn vs. Lord Baltimore $\ldots \ldots \ldots \ldots \ldots \ldots \ldots \ldots \ldots \ldots \ldots \ldots$

Penn v. Lord Baltimore........................ $\ldots \ldots \ldots$

Penn, William......................... I 1, 14-16, 18

Penns, the..................................

Pennsylvania.......... II, 13-16, 18-20, 22-27, 59-63, 95, 106, 129

Pennsylvania vs. Connecticut..................... 16, 29

Peters, Judge................................. 62-64

Petrie, W. M. Flinders......................... 118

Philadelphia.................... 16-17, 28, 30, 62-63, 78

Pierrefonds............................. I

Political Questions........................ 136-138, 152

Politiques, différends........................ 97

Princeton University ........................ 102, 109

Raeder, A...................................... 85

Randolph, Edmund Jennings...................... 34

Reed, Joseph.............................. 23-24

Rhode Island............................. 41-42

Rhode Island and Providence Plantations vs. Massachusetts,

Rhodes, James Ford.......................... 72, I09

Rittenhouse, David....................... 61, $6_{3}$

Rittenhouse, Fort........................... $6_{3}$

Rogers, Judge Henry Wade....................... 27

Roman Empire.......................... 1, 132, 133

Root, Jesse................................ 23, 25

Ross, George.............................. 20, 60-6I

Rutledge, John......................... 20, 24,32

Salisbury, Marquis of, Premicr of Great Britain............ I 18

San Juan Frontier. . . . . . . . . . . . . . . . . . . . . . 50

Schlesinger, Arthur Meier........................... 64

Scott, Dred, case, see Dred Scott.

Sergeant, Jonathan Dickinson...................... 23-24

Sherman, $\operatorname{Roger} . \ldots \ldots \ldots \ldots \ldots \ldots \ldots \ldots \ldots \ldots \ldots$. 8 , 20

Sixteenth Amendment to the Federal Constitution............. 95 
Slavery in the United States. 69-73, 78, 83, 106-107, I09, I I I, 120-121

Slaves and Teutons......................... I22

Smith, Rev. William........................ I7

Soule, Anna May............................. 64

South Carolina......................... 20, 24, 33, 35

South Carolina vs. Georgia......................... 29

South Carolina vs. Georgia....................... 56

South Dakota vs. South Carolina...................... 53

Stowell, Lord................................ 50

Strong, Jedediah........................... I6

Stuyvesant, Peter............................ 8

Summers and winters of civilization................ 132

Supreme Court of the United States..... 4-6, 3I-33, 35-36, 38-4I, $45,50,55,57-58,67-68,81-84,92,94,96,99-101,105-106$, I 09-1 12, I I 5, I I 7, I 19-1 20, I 24, I29-130, I36, I40, I 51, I $55^{-1} 5^{6}$.

Supreme Court of the World, see World Court.

Swiss Cantons.

Taney, Roger Brooke............43, 76, 80, 94, 106-107, 136

Teutons and French...................... I 22

Teutons and Slaves......................... I22

Texas..............................

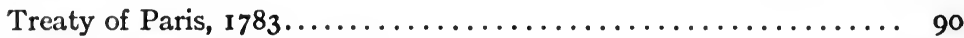

Treaty of Westminster, $1655 \ldots \ldots \ldots \ldots \ldots \ldots \ldots \ldots \ldots \ldots \ldots$

Trenton Inter-State Court............. 25, 26-29, 87, 90, 120

Tyler, Samuel............................ 76

United States............................. $\mathbf{6}_{2}$

Vattel, Emerich de.......................... 48, 135

Venezuela Boundary case..................... I03, Ir3

Venice.................................. 2

Virginia.............................. 33, 93

Virginia vs. Tennessee......................... 48

Virginia vs. West Virginia.................... 56, 57 
INDEX.

Washington, George......................... 21, 153-154

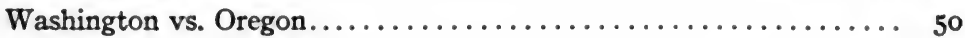

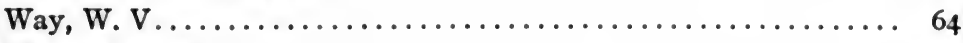

Wayne, Justice........................... 106

Webster, Daniel.......................... 41, 109

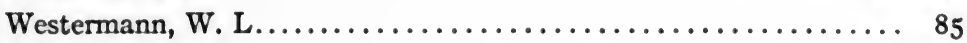

Westlake, John........................ 97, 137-138

Wharton, Francis........................... 48

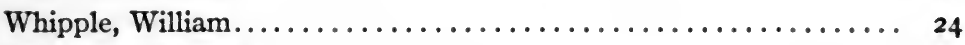

Whymper, Edward............................ 141

Willing, Thomas.............................. 20

Wilson, James.......................... 23-24, 34

Wilson, President........................... 122

Wisconsin........................... 65, 67-68

Witherspoon, John........................... 61

World Court...... 4-6, 88, 96-101, 113-114, $117,119-124,128-134$,

140-14I, 146, 151, 154

Wyoming Valley................... 14, 18-19, 21, 86, 90 




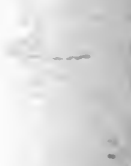

.

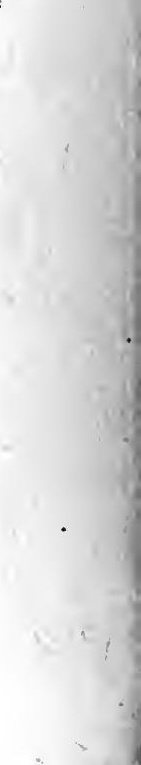




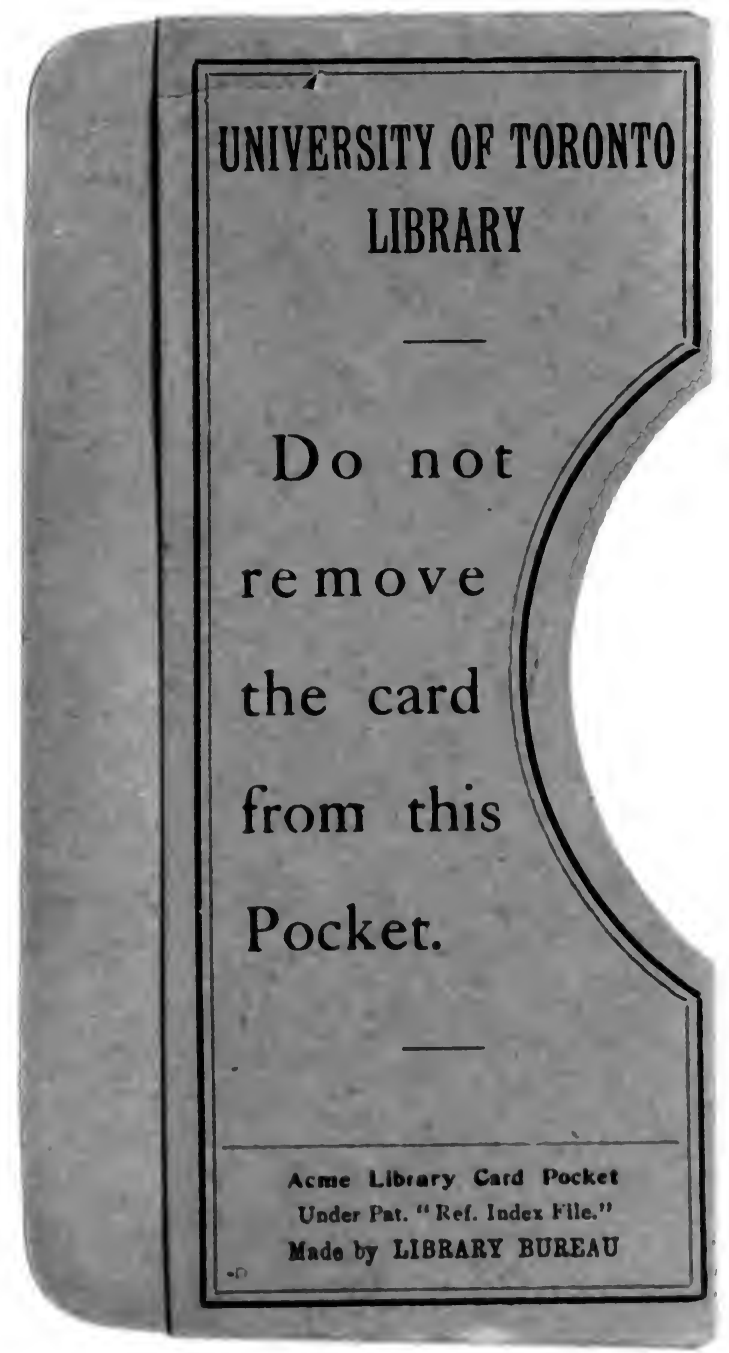


(1)

Fin

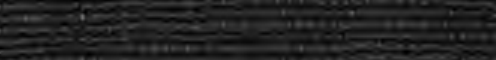

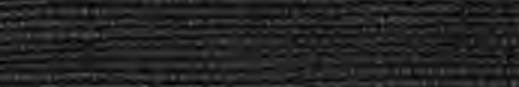

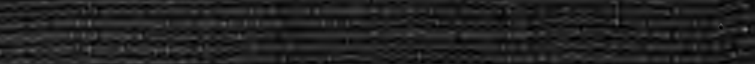

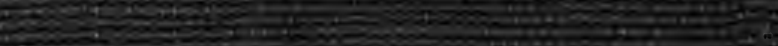

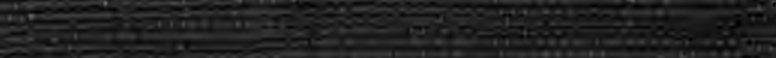

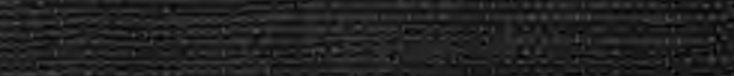

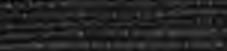

둘.

Exp-

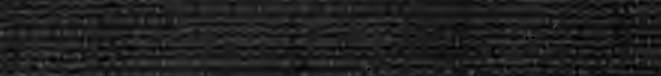

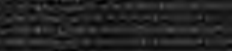

$\Rightarrow$

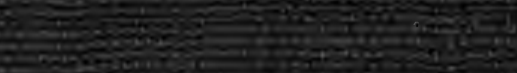

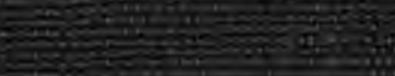

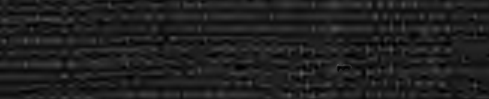

(1)

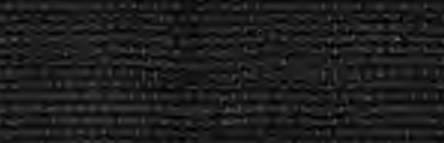

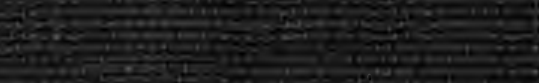

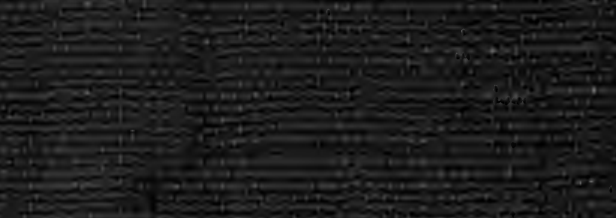

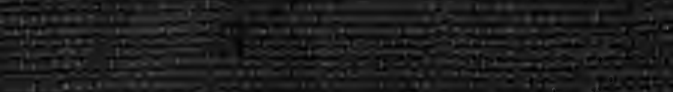

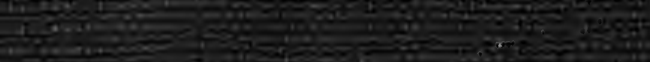

20.5.

ter.

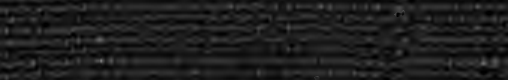

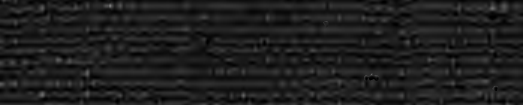

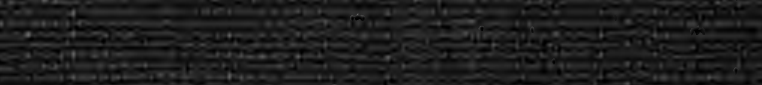

r.

(1)

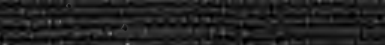

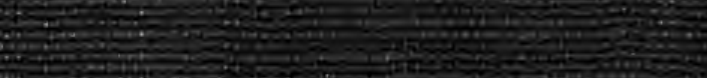

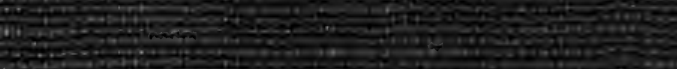

S: 